NBSIR 83-2708

\title{
Development of A Calorimeter for Simultaneously Measuring Heat Release and Mass Loss Rates
}

U.S. DEPARTMENT OF COMMERCE National Bureau of Standards National Engineering Laboratory Center for Fire Research

Washington, DC 20234

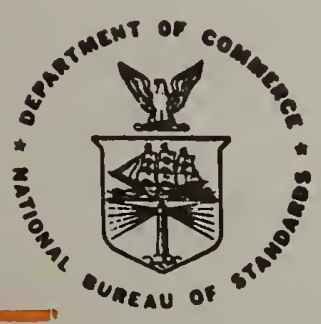

100 .456

S. DEPARTMENT OF COMMERCE

$33-2708$

1933

C. 2 

NBSIR 83-2708

...

DEVELOPMENT OF A CALORIMETER FOR SIMULTANEOUSLY MEASURING HEAT

RELEASE AND MASS LOSS RATES

John Tordella and William H. Twilley

U.S. DEPARTMENT OF COMMERCE

National Bureau of Standards

National Engineering Laboratory

Center for Fire Research

Washington, DC 20234

June 1983

U.S. DEPARTMENT OF COMMERCE, Malcolm Baldrige, Secretary NATIONAL BUREAU OF STANDARDS, Ernest Ambler, Director 



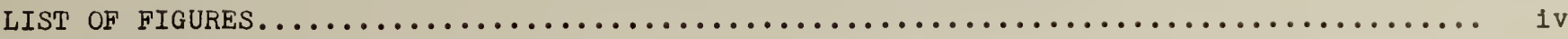

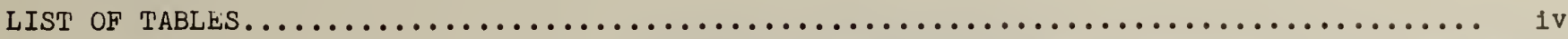

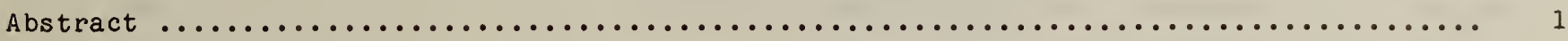

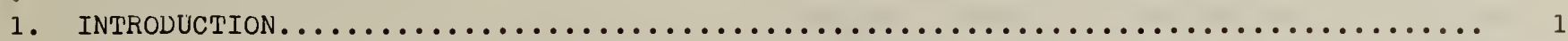

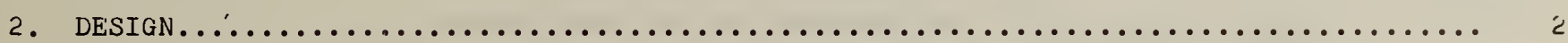

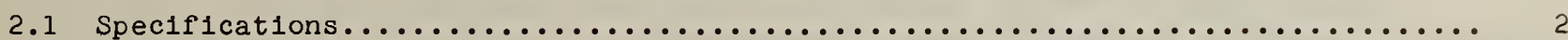

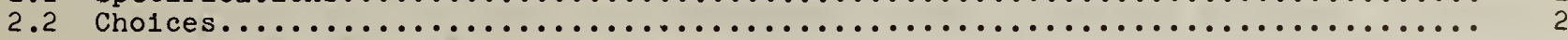

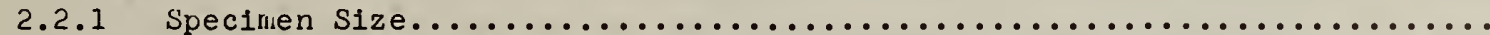

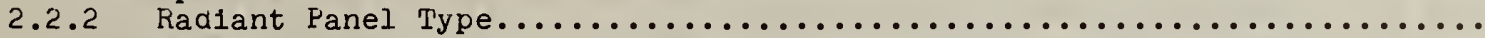

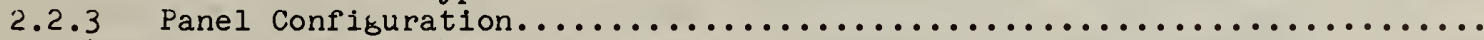

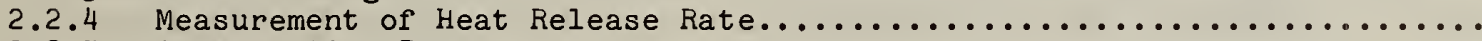

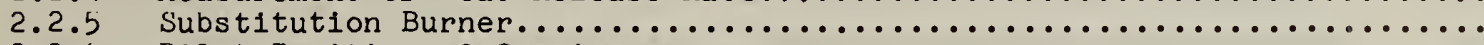

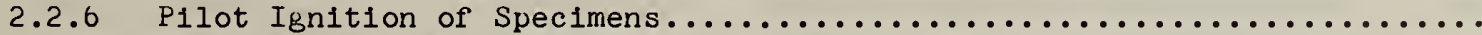

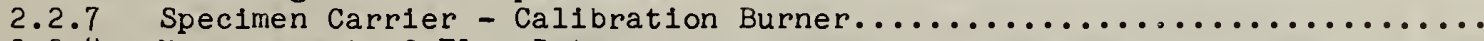

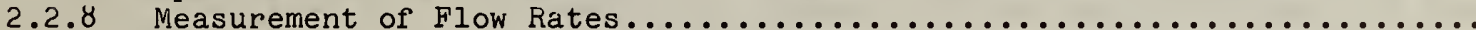

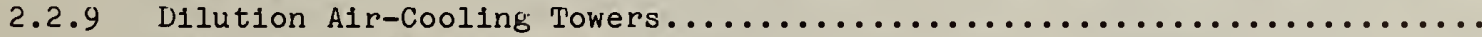

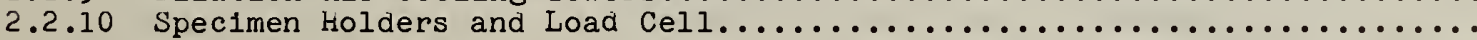

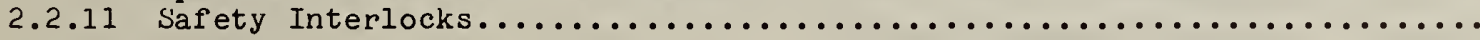

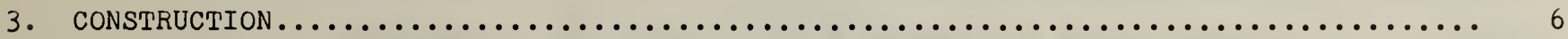

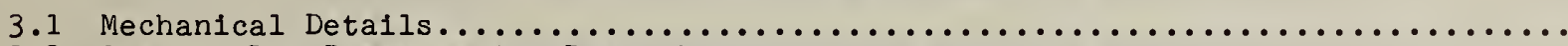

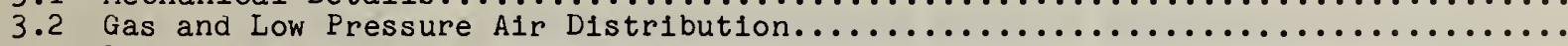

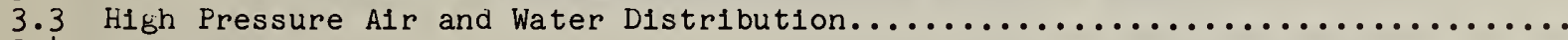

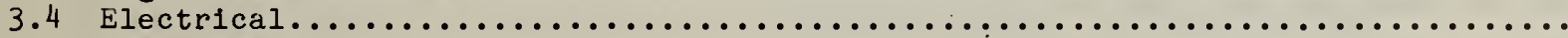

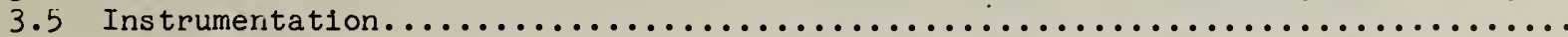

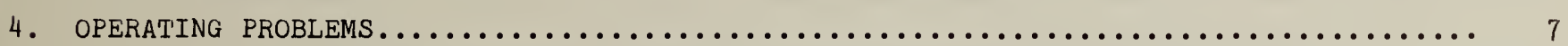

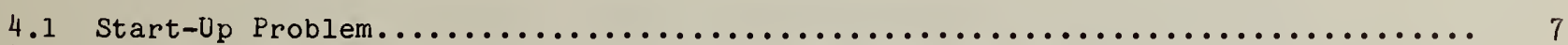

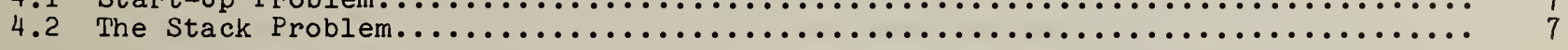

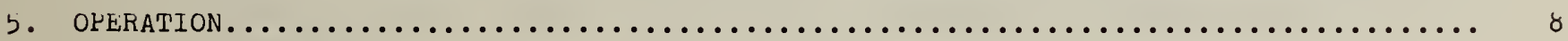

5.1 Flux Range...............................................

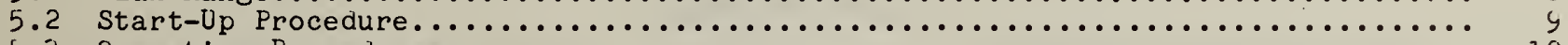

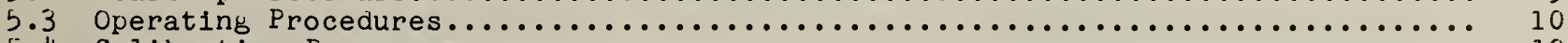

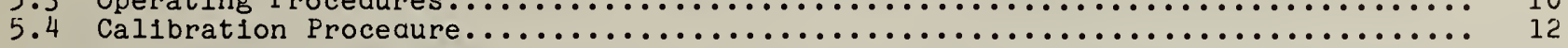

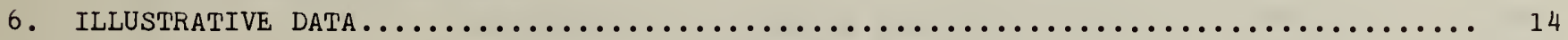

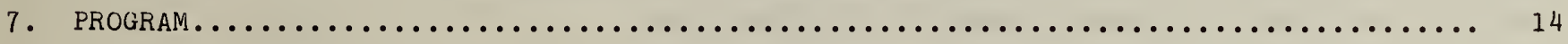

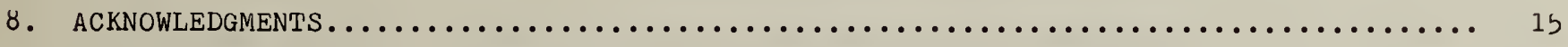

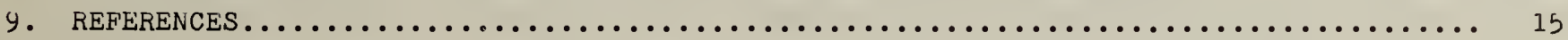


$\underline{\text { Page }}$

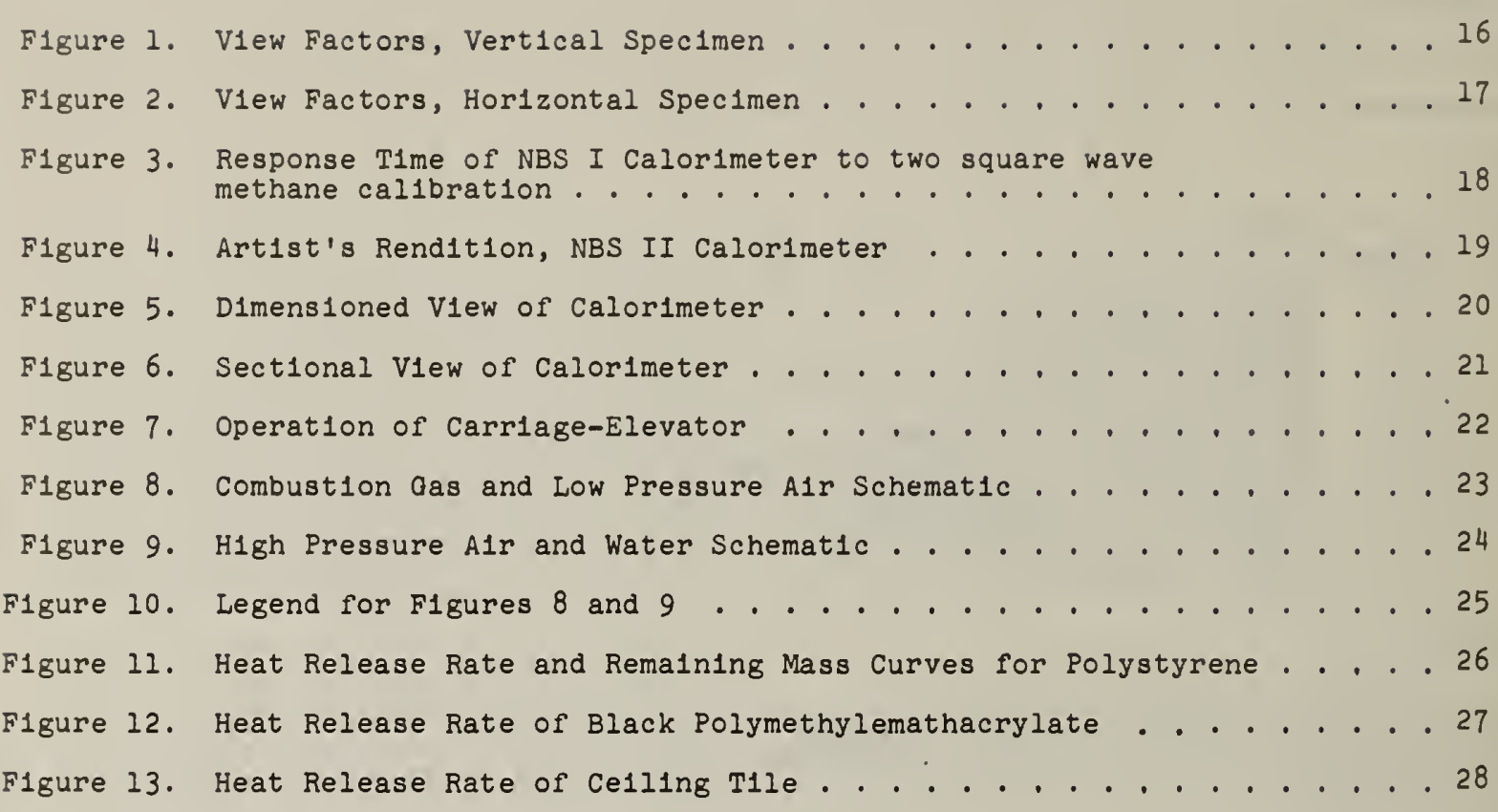

LIST OF TABLES

$\underline{\text { Page }}$

Table 1. Specification for New NBS Heat Release Rate Calorimeter . . . . . . 29

Table 2. Englneering Drawing Schedule for Calorimeter . . . . . . . . . 30 
DEVELOPMENT OF A CALORIMETER FOR SIMULTANEOUSLY

MEASURING HEAT RELEASE AND MASS LOSS RATES

\author{
John Tordella* \\ Soclety of the Plastics Industry \\ and \\ William H. Twilley \\ Center for Fire Research
}

\title{
Abstract
}

A heat release rate calorimeter (designated as NBS II) was designed, bullt, and put into operation. Specinens may be burned vertically or horizontally without the use of reflectors to provide a uniform external radiant flux fiela. The flux range 1825 to $80 \mathrm{~kW} / \mathrm{m}^{2}$. Heat release rate, mass loss rate, smoke, and heat of combustion of the unburned gaseous decomposition products are measured. The heat release rate measurement involves the use of a substitution burner technique which provides fast response. The ratio of the heat release to mass loss rates, the apparent heat of combustion, is provided as a function of time. The calorimeter may also be operated in other modes, e.g., stack temperature increase and oxygen depletion, to obtain the heat release rate.

Representative data are reported for wood and a number of synthetic polymers burned horizontally at a flux of $50 \mathrm{~kW} / \mathrm{m}^{2}$. These specimens generate considerable heat and a significant amount of uncombusted fuel.

A program involving thorough characterization of the instrument, obtaining reference heat release data for numerous materials, and conductins research in heat release rate and other flammability characteristics is recommended.

Key words: calorimeter; fire test; heat of combustion; heat release rate; mass loss rate.

\section{INTRODUCTION}

The rate of heat release by materials as they burn is recognized as an important factor governing the rate of fire growth in real world situations involving these materials. A number of devices have been used over the past 10 to 15 years to measure heat release rate [1] ${ }^{1}$. Notwithstanding, there was need for an instrument which would:

(1) accept sufficiently large specimens;

(2) operate equally well with elther vertical or horizontal specimen orientation;

\footnotetext{
- Th1s work was conducted while Dr. Tordella was a Research Associate at the National Bureau of Standards.

1 Numbers in brackets refer to literature references listed at the end of this report.
} 
(4) provide reliable data in a reasonable time.

Existing instruments were deficient in one or more of the above requirements. The Factory Mutual calorimeter developed by liewarson et al. L2j employs rather small spec1mens orlented horizontally. The Ohio State UnIversity (OSU) calorimeter [3] does not measure mass loss, has slow response, and uses small speclmens. The OSU use of a reflector for horlzontal specimen exposure with 1ts correspondins shortcominss of smoke dullins and strons reradiative effects 1ntroduce several errors. The existing Nat1onal Bureau of Standaras instrument, NBS I [4j, employs a relatively small specimen, does not provide for specimen mass loss, and has a poor geometry for horizontal specimens.

A new instrument was designed and bullt to overcome these deficlencles and satisfy the objectives set forth above. This task was begun in February 1976. Detalls of the des1gn, construction, and operation are given herein, as are lllustrative heat release data ana a recomimendea progran for future research.

\section{DESIGN}

\subsection{Spec1f1cations}

The desiun spec1fications for the new National Bureau of Standards heat release rate calorimeter, NBS II, are 81 ven in Table 1. These specifications were set by consensus of those at the Bureau who worked or had been 1nvolved in heat release rate calorimetry. The desisn specifications are those for a "state-of-the-art" heat release rate calorimeter.

\subsection{Choices}

\subsubsection{Spec1men Size}

Specimen s1zes of $300 \times 300 \mathrm{~mm}$ ( $1 \times 1 \mathrm{ft}$ ) for vertical specimens and $150 \times 300 \mathrm{~mm}$ $(1 / 2 \times 1 \mathrm{ft})$ for horizontal specimens were chosen. These sizes were expected to be suff1clently large that the data would be largely independent of specimen size. Specimen area to thlckness rat1os were ant1c1pated to be large enough that errors due to "edge effects" woula be relatively small.

\subsubsection{Radiant Panel Type}

Gas-heated radiant panels were chosen to provide the desired $80 \mathrm{~kW} / \mathrm{m}^{2}$ flux. Electric, nichrome resistance heaters do not proviae sufficlently high flux for reasonable rates of electrical yower consumption. High color temperature, short wavelensth radiation electric heaters were avolded because light and dark specimens have different absorbency at these wavelensths. Cas heated radiant panels with their longer wavelength radiation avold problems of differential absorption and more nearly represent real world fire exposures. Reflectors, usually usea with high color temperature sources, are also a problen. Loss of reflectivity due to coating by smoke particles may reduce the enersy reflected to the specimien durins a test. S1licon carbide rod heaters, which are now used in the OSU calorimeter, were not considered. These heaters are limited area sources. Declsions between the desirability of these relative to gas panels may be best arrived at through experience. 
Radiant panels manufactured by Eclipse Combustion kngineering, Inc. ${ }^{2}$ were chosen over the often used Brit1sh-made ones. The American panels had the advantages of mounting and general consulting services avallable for associated equipment supplied by the manufacturer.

\subsubsection{Panel Conf1guration}

To provide sufficlently uniform flux for horizontal specimens, the radiant panel heaters were arranged to form the four sides of a box. The horizontal specimen is located at the bottom of this box seometry. For testing vertical specimens, a holder 1s placed uprisht at the center of the heated area with the specimen "looking 1nto" the radiant panels.

The arrangement of the radiant panels is shown schematically in fisures 1 and 2 for vertical and horizontal specinens. The view factor is the fraction of the solia angle subtended by the radiant panels at the specimen face. V1ew factors were calculated Lbj for the two orientations with the panels nearly touching alony the edyes in each of the four sides and a separation of $13,2 b$, and $38 \mathrm{~mm}$ at the corners. The $38-\mathrm{mm}$ opening was chosen for the actual design because the full specimens could be viewed through these openings and because the flux range across the specimen faces did not exceed 10 percent. Various positions on the specimen are Indicated as I, II, III, etc. These correspond to center, corner, or edge, as indicated.

The size of the array of radiant panels is $600 \times 600 \mathrm{~mm}$ ( $2 \mathrm{x} 2 \mathrm{ft}$ ) and $300 \mathrm{x} 600 \mathrm{~mm}$ $(1 \times 2 \mathrm{ft})$. For the specimen sizes chosen, this size array of panels is adequate because the specimens are outside the zone of convective heating by the panels.

\subsubsection{Measurement of Heat Release Rate}

Several modes of measurement of the heat release rate were avallable. Temperature rise of stack gases due to sample combustion was the earliest method, which 1 s stil used in the osu calorimeter [3]. This constitutes, effectively, a sensible enthalpy measurement. The long response time of such an instrument was nuch reduced by use of a "substitution" burner. This scheme was to maintain a constant stack yas temperature by reducins the fuel to the substitution burner as combustion of the specimen added heat. Stack temperature is held constant by a teniperature controller actins on the fuel flow to the substitution burner. The measurement of the decrease in substitution burner fuel feed directly represents the specimen heat release. Response using both types of readouts in the first Bureau heat release rate calorimeter, NBS $I$, to two square wave methane calibrations is shown in figure 3 . With the 1sothermal substitution burner technique, full response to a step change was realized in less than 5 seconds. When the instrument was operated in the sensible enthalpy measurenient mode, full response took much longer than 1 minute.

Recently, the lag inherent in the sensible enthalpy technique was reduced by the use of a "thermal inertia compensator" with the OSU calorimeter; this is beins evaluated by an ASTM task group. A numerical compensation scheme also has been presented by Evans and Breden [6j.

Another mode of measurement of the heat release rate is by oxygen consumption. A s1gnificant number of materials liberate a nearly constant amount of heat for a given amount of oxygen consumed. While there is no inherent time las associated with oxysen consumption, there is a las associated with measurement of oxysen concentration.

2 Certain commercial equipment, instruments, or materials are 1dentified in this report in order to adequately specify the experimental procedure. In no case does such identification imply recommendation or endorsement by the National Bureau of Standards, nor does it imply that the material or equipment identified is necessarily the best available for the purpose. 
The operating cholce between the 1sothermal method and the oxygen consumption method now appears to be a matter of preference. When the NBS II calorimeter was des18ned, the $180 t h e r m i$ method was obviously the best cholce. NBS II can be operated in any of the three modes. Experience and the spec1fic task at hand will probably determine the more desirable mode.

\subsubsection{Subst1tution Burner}

A blast burner, forced air and sas, was chosen for a substitution burner. Th1s desibn permits the burner to be placed in the wall of the calorineter, out of the stream of combistion products w1thout introduction of burner thermal mass into the stream. The burner chosen was an Eclipse $40 \mathrm{AH}^{2}$ burner designed for heating a1r. It has infinite turndown, 1.e., the ab1lity to combust the fuel gas at rates from maximum to zero. Th1s is a desirable characteristic since the ent1re capacity of the burner is then avallable for the measurement of heat release rate.

Control for the substitution burner was provided by a Leeds and Northrup Electromax III 2 temperature controller with proportional band, reset, approach, and las controls. The controller operates 1nto a Kepco P1147832 power supply which drives the control valve. Th1s control valve is a fast response, solenold modulatins valve of small s1ze: Brooks Instrument Control Valve, $8948 \mathrm{~B} 037 \mathrm{BMA}^{2}$. The small size of th1s valve necessitated use of h1sh pressure $8 a s, 100 \mathrm{kPa}$ (15 ps1), to set sufficlent gas throush 1 t to accommodate a $500 \mathrm{~kW} / \mathrm{m}^{2} \mathrm{heat} \mathrm{release}$ rate for $300 \times 300$ num specimens.

\subsubsection{P1lot Ignit1on of Specimens}

Two types of specimen 1ynition are provided. Electric spark 18nition pilots are used at the top of vertical specimens and over the edge of horizontal specimens. Electric spark 1gnition pliots avold the difficulty of gas pilots which can be blown out or snuffed out by spec1men decomposition products.

A curtain pllot also was provided as an option to engulf the face of vertical spec1mens. Th1s p1lot is stationary within the calorimeter; the specimen is elevated into position beside 1t. A bottom point p1lot, such as that used with the OSU calorimeter, can be operated from the same source. Spark 1gnition of the pilot flames is provided.

\subsubsection{Specimen Carrier - Calibration Burner}

Since radiant panels surround the specimens on four sides, specimens had to be introduced from below. A rolling carriage-elevator arrangement was devised for the purpose. In the forward elevated position, the specimen holder is accessible at the front of the calorimeter. Th1s is where the speciuen is loaded on a holder, attached to the load cell. The elevator is lowered with a pneumatic cylinder, the carriage pushed back, and the elevator raised to bring the specimen within view of the radiant panels. Figure 7 shows this operation pictorially.

The elevator was made with two sides. The second side is used to carry a diffusion flame plpe burner, which provides a convenient mode for calibration. Were calibration sufficiently infrequent, the line pliot could be usea for this purpose and the second position could be used to mount a second specimen holder. If both vertical and horizontal specimen holders were mounted, tedious exchange of holders could be avolded. However, this would require an add1tional load cell arrangement for measuring the mass loss. 


\subsubsection{Measurement of Flow Rates}

Orifice gauges were used to measure the flow rate of dilution air, air to the substitution burner, air to the radiant panels, and gas to the radiant panels. Mass flow meters were provided to measure gas to the substitution and calibration burners. A variable area flow meter was provided to check the accuracy of the mass flow meter on the calibration burner.

\subsubsection{Dilution Air-Cooling T'owers}

Dilution air, additional air beyond that required for combustion either of the specimens or of gas from the various burners, is introduced for several reasons. In the event that energy balance is to be calculated, sufficient dilution air will permit use of thermal data for air rather than having to use data for the individual combustion products. Another reason is that dilution air lowers the temperature of the instrument significantly.

The possibility of ignition of the premixed gas and air within the radiant panels was thought to be a problen. Irradiation of one panel by another in the box configuration could raise the temperature of the metal parts of the burner sufficlently that the premix would ifnite and destroy the procelain burner panels. To avold this possibility, dilution air was introduced through an air manifold at the base of the calorimeter and directed up vertical pipes, called cooling towers to the back of each radiant panel. One cooling tower was located behind each vertical burner array. Parts in each tower directed air at the bolts holding each burner onto its manifold. The air was to cool the back of the burners.

The cooling of the burner backs themselves described above was found to be unnecessary Operation at maximum flux with no dilution air flow produced a temperature of only about $400^{\circ} \mathrm{C}$ at the back of the porcelain panel plaques. The ignition temperature for natural gas-air mixtures is about $500^{\circ} \mathrm{C}$. Even though the cooling of the burner backs was found to be unnecessary, their use was found to be desirable for keeping the sheetmetal shrouds cooler. Cool shrouds help keep the room housing the calorimeter more comfortable to work in and reduce the possibility of personnel getting burned.

\subsubsection{Specimen Holders and Load Cell}

Vertical and horizontal specimen holders were designed with water-cooling elements between the holder and load cell. The whole frame for the vertical holders was water-cooled. Connection for the cooling water was done through pliant coils of copper tubing which did not rub or touch anything. Friction from touching would result in "backlash" and step-like weight versus time curves. The load cell was mounted in a five-sided stainless steel box, each side of which is water-cooled.

\subsubsection{Safety Interlocks}

There are explosion hazards associated with the use of gaseous fuels. Safety interlock devices and conservative design were employed to reduce the hazard. The calorimeter has the following features designed for safe operation. The flue gases from the calorimeter go directly through the building roof by way of the instrument's own stack; bypassing the bullilny's central hood and duct exhaust system. This stack assures that uncombusted natural gas does not enter the building's exhaust ducts and create an explosion hazard. There is a pressure interlock switch on the dilution air to the instrument downstream of the butterfly throttling valve. If the dilution air is not flowing to the instrument, the interlock switch 
causes the nain gas valve to close. Th1s avolds accumulating explosive concentrations of gas w1thin the instrument. The 1nstrument stack and dilution alr pressure switch constitute the main safety features. An additional safety device consists of a "flane rod". Th1s 18 a device which senses whether there 18 a flame on the surface of the radiant panel and causes the main gas valve to shut down if the flame goes out. Th1s device is installed on the radiant panels that are operated for both vertical and horizontal specimens. The hazard that this device protects against is the gas golng of $f^{\prime}$, then coming back on again and not belng 1gnitea. W1th the flame rod, the maln gas valve will close when the flane goes out and will not reopen if the gas comes on later.

A hood over the specimen loading and unloading station protects the operator against f'umes from the specimen residues. Curtains can be installed if greater alr velocity past the operator is needed.

\section{CONSTRUCTION}

\subsection{Mechanical Detalls}

Mechanical detalls of the calorimeter are described in the group of englneering drawings 11sted in table 2. An artist's rendition of the instrument, figure 4, 1llustrates the main features. A almensioned view of the calorimeter is shown in figure 5. The callbration burner is shown within the array of radiant panels, in the sectional view of flgure 6 . The cooling towers carrying dilution air are also shown. The main base of the instrument is a rectangular frame of $150 \times 300 \mathrm{ma}$ rectangular tubing about $1 \times 1-1 / 2 \mathrm{~m}(3-1 / 2 \times 4 \mathrm{ft}$ ) overall. Th1s frame also serves as the dilution air manifold. An angle 1ron frame on the main instrument frame supports the shrouds which have windows for viewing the burning specimens. The shrouds const1tute a box about $1-1 / 3 \mathrm{~m} 1 \mathrm{n}$ length, w1dth, and helght. A transition to a rectangular stack s1ts atop the shroud support frame. The thermocouples which monitor flue gas temperature are about $1-1 / 3 \mathrm{~m}$ above the top of the transition. The whole instrument is supported by rigla angle 1ron legs welded to the dilution air manifold. The sample carriage-elevator arrangement rolls between the legs on aluminum support ralls hung from the dilution air manifold. F1gure 7 shows the operation of the carriage-elevator moving the vertical sample holder from outside the calorimeter, where samples are loaded and unloaded, to the 1nside of the calorineter exposing them to the radiant panels.

\subsection{Gas and Low Pressure A1r Distribution}

lias and low pressure air piping to the calorimeter are shown in figure 8 . The air pressure $1 \mathrm{~s}$ applied by the blower at $5.2 \mathrm{kPa}\left(12 \mathrm{oz} / \mathrm{in}^{2}\right)$.

\subsection{High Pressure A1r and Water D1stribution}

A schematic drawing of high pressure alr and cooling water to the calorimeter is glven in flgure $y$. The legend for figures $b$ and $y$ is found in figure 10 .

\subsection{Electrical}

Electrical power for the calorimeter 1 s supplied by a single 120 volt 60 -cycle 20 amp c1rcuit. A sinfle switch on the control panel deactivates the calorimeter, electrical, air blower, water, and instrumentation. Compressed air to hold the sample elevator up remains always on. 


\subsection{Instrumentation}

Flow rate of 8 sas to the substitution burner 18 measured by a Datametrics $800 \mathrm{LM}^{2}$ mass flow meter of $0-2.36 \mathrm{~L} / \mathrm{s}\left(0-5 \mathrm{ft}^{3} / \mathrm{min}\right), 0-10 \mathrm{~V}$ output. The output signal goes to a signal cond1tioner which inverts it and provides a continuously adjustable gain. This adjustable gain allows the output to be rationalized so that a recorder may read directly in $\mathrm{kW} / \mathrm{m}^{2}$ heat release for a given specimen size.

Flow rate to the calibration burner of the specimen pilots is read on a second identical mass flow meter without a signal conditioner. A variable area flow meter is used optionally in series with the mass flow meter to check the callbration.

Specimen weight is measured with an Automatic Iiming Control series $6005 \mathrm{C}^{2}$ weigh cell and denodulator model $6101-\mathrm{F}^{2}$. The welgh cell range is $0-2 \mathrm{~kg}(0-4 \mathrm{lb})$ with $12 \mathrm{~kg}$ (26 lb) tare we1ght adjustment.

The snoke meter was designed by J.S. Steel. It consists of a laser light source, Metrologic ME- $620^{2}, 0.8 \mathrm{~mW}$, and a 1 P39 phototube receiver with a logarithmic amplifier. The output is $0-b$ volts, which corresponds to $0-5$ optical density units.

The combustion meter is a Leeds and Northrup total combustible gas analyzer, $\# 7867-4-3-1-005-0-2-1-00-0^{2}$. The output is $0-10 \mathrm{~V}$ for $0-5$ percent combustibles.

A Gardon flux gage, $0-100 \mathrm{~kW} / \mathrm{m}^{2}$, is used to monitor the flux incident on the specimen, either vertical or horizontal. The output is about $0.0125 \mathrm{mV} / \mathrm{kW} / \mathrm{m}^{2} \mathrm{flux}$.

A six point, console Rikadenko recorder ${ }^{2}$ is used adjacent to the calorimeter. The data can also be taken digltally, stored on discs, and later reduced on a minicomputer in another buildint.

\section{OPERATING PROBLEMS}

\subsection{Start-Up Problem}

Completion of the instrument took many months. The large parts were completed by the main shop in July 1977. Sheet metal, plumbing, and electrical work were done in mid November 1977; instrument-type plumbing, electrical, and mechanical work went on until June 1978 .

Once the basic assembly work was completed and start up testing begun many new problems appeared. Even with the commercially purchased ignition system, reliable panel ignition took much trial and error fitting the sample load cell and carriage-elevator worked well when the calorimeter was cold but became erratic or jammed when the calorimeter was at normal operating temperatures. These problems were ultimately overcome by reinforcing the calorimeters base and judicious use of water cooled shielding.

\subsection{The Stack Problem}

The single most serious problem in operation has been that of fluctuations in rate of flow of gas to the substitution burner, under steady operatins conditions. These fluctuations were ultimately found to be the result of variable wind velocity at the top of the stack, resulting in a pressure differential as larse as 50 to $75 \mathrm{~Pa}\left(0.2\right.$ to 0.3 in $\left.\mathrm{H}_{2} \mathrm{O}\right)$. 
The best baseline uniformity, 1.e., the gas flow rate at steady conditions w1th no specimen in the calorimeter, corresponded to \pm 2 to $3 \mathrm{~kW} / \mathrm{m}^{2}$ on $300 \times 300-n m$ specimen basis. During gusty winds precediris a rain squall, the baseline varied randomly over a range or 100 to $150 \mathrm{~kW} / \mathrm{m}^{2}$. On a gusty winter day, baseline variation was often 50 to $100 \mathrm{~kW} / \mathrm{m}^{2}$. The tolerable maximum is about 10 to $20 \mathrm{~kW} / \mathrm{m}^{2}$.

The first approach to solving the stack problem was to install (a) a venturi type cap on the stack to prevent "downdrafting" and (b) a barometric damper in the stack. The rationale was that the ventur1 cap would assure a negat1ve stack pressure and the damper would modulate the negat1ve pressure to a constant value. This approach did not solve the problem. The stack pressure was not sufficiently negative for the barometric damper to function.

Two other approaches were trled unsuccessfully:

1. A1r flow through the instrument was increased to a maximum so that the stack pressure change due to the wind would be a smaller part of the total pressure drop. The fuel flow variation was reduced, but large positive pressure in the calorimeter, about $25 \mathrm{~Pa}\left(0.1 \mathrm{in} \mathrm{H}_{2} \mathrm{O}\right)$, was objectionable. Combustion products leaked out into the room causing eye and throat discomfort, and possible toxic1ty problems.

2. A1r flow was mininized and the substitution burner was operated at cauac1ty. The objective was to maximize the draft in order to cause the barometric damper to function. The draft produced at $430 \mathrm{C}$ was inadequate, about $12.5 \mathrm{~Pa}\left(0.05 \mathrm{in} \mathrm{H}_{2} \mathrm{O}\right)$, to operate the damper. (Insulating the stack would also increase the draft. Calculations indicated only about a 10 percent increase in draft could be obta1ned, which was considered to be inadequate.)

Increased stack height to get above eddies caused by the building did not appear to be a viable solution. Significant pressure variations occurred even in the main stack, which is about $7.6 \mathrm{~m}$ (25 ft) taller than the calor1meter stack. Arch1tectural pract1ces at the Bureau militate against a stack taller than the maln bullding stack.

The variable stack pressure problem possibly could be solved by 1nstalling a draft inducing blower and an adjustable damper in series in the stack. The objective is to create a large pressure change going up the stack such that the pressure variation due to eddies $1 \mathrm{~s}$ relatively small. A pressure of $1.25 \mathrm{kPa}\left(5 \mathrm{in} \mathrm{H}_{2} \mathrm{O}\right)$ appears to be a good goal. The capacity of the blower must be adequate to handle the volume of the calorimeter stack gases. Pressure in the calorimeter 1 tself shoula be neutral. Calorimeter pressure can be adjusted by varying the damper opening. The barometric damper should be removed to reduce the effect of pressure changes due to opening and closing bullding doors on calorimeter operation. This design change might improve the stability of the baseline but at present 1 has not been tried, limiting optimun calorimeter operation to relatively calm days.

\section{OPERATION \\ 5.1 Flux Range}

The radiant panels operate over a pressure range of about $100 \mathrm{~Pa}\left(0.4\right.$ in $\left.\mathrm{H}_{2} \mathrm{O}\right)$ to a design maximum of $870 \mathrm{~Pa}\left(3 . \mathrm{b}\right.$ in $\left.\mathrm{H}_{2} \mathrm{O}\right)$. The associated flux range is about 25 to $80 \mathrm{~kW} / \mathrm{m}^{2}$. 


\subsection{Start-Up Procedure}

Check maln panel to be sure all switches are OFF.

Turn main power switch on panel to oN (level handle). This will activate the following functions:

- main panel power on,

- opens cooling water solenold valves,

- enérgizes both duplex recepticles on power panel,

- energizes control system,

- energizes data system,

- energizes air pump and combustion analyzer, and

- energizes laser on smoke meter.

Turn air blower on by pushing green START button.

This will turn on the air blower in the equipment room -- wait for yellow light -- and will close the air pressure safety switch to supply power to main gas valve.

If yellow light does not come on within 2 minutes, increase the air flow by opening valve 35.

Open gas valve 8 for samples being tested in the vertical sample holder or valves 7 and 8 for samples beins tested in the horizontal sample holder.

Open yate valve 32 for vertical samples or valves 32 and 33 for horizontal samples to $250 \mathrm{~Pa}\left(\mathrm{I} 1 \mathrm{r} \mathrm{H}_{2} \mathrm{O}\right)$ or more of premixed gas and air.

Turn radiant panel switch on main panel from OFF to IGN and hold on IGN unt 1 red lisht comes on.

This will activate the following:

- spark igniters on face of radiant panels will ignite panels, and

- main gas valve will be held open by flame rod relay when flame 1s established and pilot light comes on.

Turn substitution burner switch from OFF to IGN to ignite pilot flame for substitution burner.

The following controls are located on the control panel. Turn the substitution burner controller toggle switch from MANUAL to AUTO.

Turn voltage control knob to the maximum settins that does not open substitution burner valve, about "ll o'clock".

Turn temperature controller knob to $220 \mathrm{C}$ or greater.

Turn toygle switch to signal conditioner to ON. 
Turn tosgle switch for power to controller ON to activate the substitution burner.

Turn combustion analyzer toggle switch to $\mathrm{ON}$.

Turn smoke meter analyzer togsle switch ON.

Turn toggle switch on outlet box on main panel ON to activate laser, smoke pump, ana smoke anlayzer.

Turn analog to digltal converter tobgle switch ON.

Turn both modems table units ON by operating rocker switches on back of units.

Turn on strip chart recorder by switching oN main power switch on front of recorder.

Turn on all rocker switches for each individual pen, on top of recorder.

Set chart sueed as desired.

This concludes the start-uy procedure.

\subsection{Operating Procedures}

Once the calorimeter is started, it is necessary to set several variables to the desired levels. First, 1t is necessary to establish the orientation of the sample, elther horizontally or vertically. Second, the slze of sample to be tested must be established. The standard maximum size for horizontal samples is $150 \times 300 \mathrm{~mm}$ ( $1 / 2 \times 1 \mathrm{ft}$ ) and for vertical samples $1 \mathrm{~s}$ $300 \times 300 \mathrm{~mm}$ ( 1 x I ft); smaller sizes may be used. The thickness of the sample is limited primarily by the sample holder being used. Th1rd, the type of sample 1gnition must be established -- elther gas flame, electric spark, or no 18niter. Once these variables have been establ1shed, NBS II must be adjusted to meet them. Horizontal samples require a pan or tray approximately the same size as the sample to be tested to rest on the insulation above the load cell.

Vertical samples require installation of a special frame to be mounted on the load cell. This can be accomplished by moving the carriage elevator so the load cell is outside the calorimeter. This is the normal position of the carriage-elevator when loadins and unloading samples. The vertical sample holder is then bolted to the load cell, and the coolins water connections are made. The flux meter should be attached to the side of the sample holder and the water and electric lines for 1t connected. The water lines must be pliant and must not touch each other or any part of the frame or the load cell output will be erratic. Once the vertical sample holder is in place, samples are inserted into the holder backed up with ceramic insulation board and secured with spring clamps.

With the sample holder positioned, it is necessary to install the sample 18niter system, if one is going to be used. The spark isniter on the horizontal sample holder involves the use of a spark plug with a long tip and ground electrode. This spark plug is held on a metal strap which can position the electrodes over or near the sample. Voltage for the spark 1s p1cked up by way of an $18 \mathrm{~cm}(7 \mathrm{in})$ long wire which engages a high voltage wire frame inside the stationary part of the calorimeter. Th1s igniter can be attached and adjusted while the calorimeter is in operation. 
The spark 1gniter for the vertical sample holder attaches to the top of the sample holder, and employs a similar type of spark plus as the one used on the horizontal sample holder. This spark plug also engages a high voltage wire frame inside the calorimeter. It can be attached and adfusted while the calorimeter is in operation.

The gas 18niter for both the horizontal and vertical sample holders uses a stainless steel tube with holes in the end to generate an igniter flame. The pilot flame for the horizontal sample holder may be positioned above or alongside the sample simply by bending the tubing slightly. The 1gniter flame for the vertical sample is placed in front of and below the sample holder. In this position, elther a small igniter flame or a sheet igniter flame may be used. The sample igniter is supplied by way of a solenold controlled gas valve. To Install the gas ifniters for elther the horizontal or vertical holder, the calorimeter is turned off and allowed to cool. The back panel is removed by takinf out fourteen 10-32 hex head screws and lifting it off. This will give access to the fittings on the solenold controlled gas line. The appropriate igniter is connected to the gas line using the compression fittings supplied. The back cover is replaced and the calorineter started up.

It is now necessary to set the flux levels. With the calorimeter operating, the appropriate sample holder is inserted into the calorimeter so that the flux meter is facing the radiant panels. Note that when using the vertical sample holder, only those radiant panels facing the sample will be used. The other half of the radiant panels will be turned off. Adjust the gate valves 7 and 8 , or valve 8 only for vertical samples, to obtain the desired flux. An hour warm-up is required to assure that a steady state has been reached.

The substitution burner is set to about $1.9 \mathrm{~L} / \mathrm{s}$ ( 4 SCFM) on natural gas, as read on the mass flow meter*. This will yield near maximum turn down measuring capacity without seriously affecting the elevator operating transient. Settings of below $1.9 \mathrm{~L} / \mathrm{s}$ ( 4 SCFM) or above $2.1 \mathrm{~L} / \mathrm{s}$ ( $4.5 \mathrm{SCFM}$ ) tend to give an excessively slow recovery time when the elevator is operated. Some samples may cause the substitution burner to shut down completely; hence, peak heat release rate from a saniple will not be ascertained. If this occurs, the sample size must be reduced so that peak heat release will be within the range of response of the substitution burner.

In setting the dilution a1r, it is desirable to control the dilution air going into the calorimeter to provide a neutral pressure condition near the specimen helght level in the calorimeter. To acconplish this, adjust dilution air valve 35 until the manometer reading air pressure in the calorimeter is about zero. Take note that closing valve 35 too far may cause the pressure safety switch to trip out and shut down the calorimeter. If this occurs, open valve 35 back up and restart the calorimeter. It is advisable to strive for a neutral or balanced air pressure, as a strong positive pressure will cause much loss of heated air when the elevator is operated. This heat loss will exaggerate the recovery time for the substitution burner. Likewise, an excessive negative pressure inside the calorimeter will draw in cold air when the elevator is operated, also resulting in a worsening of the recovery time for the substitution burner.

Once the dilution air has been set, it may be necessary to reset the substitution burner gas flow rate back to $1.9 \mathrm{~L} / \mathrm{s}$ ( $4 \mathrm{CFM}$ ). With the dilution air, substitution burner, and flux set, the calibration procedure should be carried out before testing any samples. Unce this calibration procedure is completed, the operation of the calorimeter in testing a sample

* This adjustment is made by setting an appropriate value for the stack thermocouple grid temperature, typically about $220^{\circ} \mathrm{C}$. 
Involves simply inserting the sample in the appropriate sample holaer, operatins the elevator to brins the sample inside the calorimeter, and operatins the switch "1unition specimen p1lot" if a spark igniter is to be used. W1th the gas flane igniter, the "1gnition specimen p1lot" switch need not be operated as the flame size has been set ana is left burning all the time. Once the test is conpleted, remove the old sanple and replace with a new sample and proceed as above.

\section{4 Calibration Procedure}

Certain elements of the calorimeter should be checked before each day's run. These 1 tems include the mass flow meters, strip chart recorder, flow to calibration burner, substitution burner turn down, and the welgh cell. All callbration tests should be performed after the calorimeter has had a warm-up perlod of at least one hour.

Calibrate the mass flow meters first. To do this, proceed as follows:

1. Turn mass flow meters OFF; set the mechanical zero on the meter face. Needle should read exactly zero with the unit off. If not, adjust the mechanical zero with a small screwdriver.

2. Iurn the mass flow meter ON, w1th calorimeter at operatins temperature; proceed to aajust the meter.

3. Adjust zero flow readings.

(a) Shut of $g$ as valves 14 and 20 completely, stopping flow to meter sensors.

(b) Set function switch to clean and hold for 5 seconds.

(c) Set function switch to CALIBRATE and the three-position toggle switch to $B A L$; the needle should read exactly "O" on the top scale. If not, adjust the BAL screwdriver potentiometer unt1l the reading 1 sero.

(d) Set the three-position toggle switch to 1ts downward position FS. The meter should read full-scale within $\pm 1.2 \mathrm{~cm}(+1 / 2 \mathrm{ln})$ Adjust the FS screwdriver potentiometer until the reading is full-scale.

(e) Return the three-position tos8le switch to 1ts center position, ZERO. The meter should read zero within $1.6 \mathrm{~mm}(1 / 16 \mathrm{ln})$. Adjust the ZERO screwdriver potentiometer until the reading is zero.

(f) Reopen valves 14 and 20 and let the substitution burner equilibrate.

Th1s completes the electronic calibration of the mass flow meters. The mass flow meters must also be callbrated against the variable area flow meter. This test insures that the mass flow meters have not lost their callbration. It also assures that the conposition of the natural yas being supplied to the calorineter has not changed. To perform this cross check test, turn subst1tution burner control to MANUAL, open valves 25, 51, 54, and 21 ; close valves 20, 22, and 53. The gas is now set to flow through the variable area flow meter and the sensing unit, numbers 16 and 24 of the mass flow meters. Make certain that the calibration 
burner is properly positioned inside the calorimeter. Open modulating soleroid valve 15 and set control valve voltage knob to approximately "12 o'clock". Open gas cock number 14 and ignite the gas flowing to the calibration burner. Both mass flow meters should read $0.5 \mathrm{~L} / \mathrm{s}$ ( $1.0 \mathrm{SCFM})$. If not, adjust the control valve voltage knob unt1l both meters read exactly $0.5 \mathrm{~L} / \mathrm{s}(1.0 \mathrm{SCF} M)$. Check the varlable area flow meter; 1t should read $0.36 \mathrm{~L} / \mathrm{s}$ (46 SCFH). If varlable area flow meter reads $\pm 1.0 \mathrm{~L} / \mathrm{min}( \pm 2 \mathrm{SCFH}$ ) different from $0.36 \mathrm{~L} / \mathrm{s}$ ( $46 \mathrm{SCFH}$ ), recal1 brate the mass flow meters. If variable area flow meter reads $\pm 1.0 \mathrm{~L} / \mathrm{min}$ ( $\pm 2 \mathrm{SCFH}$ ) of $0.36 \mathrm{~L} / \mathrm{s}$ ( $46 \mathrm{SCFH}$ ) (but not exactly), record this difference, as 1 t will be used as a calibration correction. With this completed, reset all appropriate valves to their normal operating position. This completes meter calibration. Just before running any series of heat release experiments, it is necessary to make one final calibration. With all the above meter checks completed and the calorimeter operating, place the calibration burner into the calorimeter, open valves 20,21 , and 25 , and adjust the natural gas flow on the variable area flow meter to $0.36 \mathrm{~L} / \mathrm{s}$ ( $46 \mathrm{SCF} H$ ) using valve 54. Ignite the gas and note the response the substitution burner gives on the strip chart. From this calibration, all subsequent heat release calculations can be made.

The strip chart recorder must be calibrated, as the output frorn this recorder will be used to set other parameters. First, set the zero set point for all the pens. With all pens operating and the chart running, turn all six attenuator knobs to of $($ short). All the pens w1ll give a straight line trace at some point on the chart. These pens may be moved to any convenient point on the chart by use of the zero adjuster knobs. With the zero set point established start turning the attenuator on; first pen numbers 1 and 2, the substitution burner, and substitution burner with signal averager to the 10-volt mark (full-scale). These pens should be in the left quarter of the chart when the substitution burner is consuming approximately $2.0 \mathrm{~L} / \mathrm{s}(4.0 \mathrm{CFM})$ of natural gas. These pens should move toward the right side of the chart as the substitution burner gas flow is reduced. A quick check on this is to simply switch the power toggle switch to the substitution burner controller of and determine if the pens stay within the chart boundaries.

The flux pen (number 3) is turned from zero (short) to 10 millivolts (full-scale). This pen moves from left to right as flux increases. For every $1 \mathrm{~m} 1 \mathrm{llivolt}$ increase in output, the actual flux increases approximately $12.5 \mathrm{~kW} / \mathrm{m}^{2}$. To check the actual flux, 1nsert the appropriate sample holder (horizontal or vertical) and flux gage and read the output in millivolts from the zero (short) point. Multiply the millivolt output by 1.26 , the constant for the flux gages; this will yield the actual flux falling on the flux meter. To increase or decrease flux, use valves 7 and 8 .

The optical density smoke meter (pen 4) is turned from the zero (short) set point to the 5-volt full-scale position. This pen moves from left to right and, for every volt increase in output, the observation is increased 10-fold. There is no calibration check for the optical density output.

The combustion meter (pen 5) is turned from the zero (short) set point to the 1-volt fullscale position; the pen will move off the zero point and establish a new equilibrium point. This pens moves from left to right. To calibrate the combustion meter, insert the calibration burner into the calorimeter, and open the solenold gas valve to the calibration burner by turnins the switch "Calibration Burner" to ON. Set the variable area flow meter to $0.36 \mathrm{~L} / \mathrm{s}$ ( $46 \mathrm{SCFH}$ ). Do not 1gnite the gas. The pen w1ll move to the right to about 0.65 volts. The pen should register a $0.0712-v o l t$ change for every $5.0 \mathrm{~L} / \mathrm{min}(10-S C F M)$ change in the rotometer. If this rat1o changes, invest1gate the molsture trap and paper filter on the combustion meter sampling line for possible obstruction. 
The welgh cell (pen 6) is turned from the zero (short) set position to the 1-volt level full-scale for samples welghing up to 500 grams. Heavier samples may be welghed by turning the demodulator range sw1tch from zero to 100; at this setting, samples of 1000 grams may now be used. The welgh cell is callbrated by simply placing a known weight on the sample holder and noting the response pen 6 ylelds. It 1 s often quite helpful to start by plac1ns 50 grams on the sample holder and workins up to a total of 500 srams. The output of pen 6 shoulo be 1 n step fashion corresponding to the added welohts applied. From this cal1bration, a sram/ division ratio may be developed.

\section{ILLUSTRATIVE DAT'A}

The f1rst test in the NBS II calorimeter was on a $75 \times 30 \times 13$ num ( $3 \times 1 \times 1 / 21 \mathrm{n})$ polystyrene specimen in the horizontal orlentation using the 1sothermal mode of measurement. A trac1ng of the or 181 nal heat release rate and mass remaining curves are shown 1 f figure 11.

Heat release rate measurements were made by Babrauskas [7] on black polymethylmethacryate using the oxygen consumption techn1que. The samples were $100 \times 100 \times 13 \mathrm{~mm}(4 \times 4 \times 1 / 21 \mathrm{n}$ ) and were mounted horlzontally. The mean values for six sets of measurements together with the standard deviation 1 s plotted in figure 12. An extensive series of heat release rate tests were run on wood products by Chamberla1n [8]. A tracing of an or1g1nal data curve for a vert1cal specimen of celling tile, $300 \times 300 \times 13 \mathrm{~mm}\left(12 \times 12 \times 1 / 2 \mathrm{ln}\right.$ ), exposed at $50 \mathrm{~kW} / \mathrm{m}^{2}$ and measured in the 1sothermal mode is seen in figure 13.

\section{PROGRAM}

The new heat release rate calorineter, NBS II, appears to be a good qual1ty instrument with broad potential for fire research.

The following research program 1s sugsested for 1ts use:

a. measure for representat1ve materials:

\author{
heat release rate \\ mass loss rate \\ smoke \\ uncombusted fuel
}

\author{
syecimen size \\ specimen orlentation \\ air velocity \\ type of plloting
}

b. compare the heat release rate measured directly by oxygen consumption in the NBS II;

c. compare the data obtained w1th NBS II w1th the data from NBS I, OSU, and instruments based on oxygen consumption;

a. recommend conditions of measurement for heat release rate on the bas1s of the experience and understanding galned above;

e. publish heat release aata for an extended srouy of materials measured in the recommended way (these data could const1tute the beginning of a handbook of data describing combustib1lity of mater1als); and, 
f. determine the effect of materlal composition (carbon, hyarogen, halogens, oxyzen) on heat release rate -- compare the heat release rates of cellulosic and synthetic polymers.

\section{ACKNOWLEDGMENTS}

The development of the new calorimeter was supported in large part by the Society of the Plast1cs Industry who sponsored Dr. Tordella as a Research Associate at the Bureau from February 1, 1976 through July 31, 1978.

Many people helped in this period, and speclal thanks are extended to them. A partial list 1s W.J. Parker, supervisor; M.M. Brown and J.M. Loewe, secretaries; J.S. Steel, physicist; W.H. Bailey, supervisor of Building 205; J.G. LaRock, designer draftsman; and H.E. Brown, welding shop supervisor.

\section{y. REFERENCES}

[1] Chamberlain, D.L., "Rate of Heat Release -- Tool for the Evaluation of the Fire Performance of Materials", presented at the Joint Meeting of the Central and Western States Section of the Combustion Institute on Flammability and Burning Characteristics of Materials and Fuels, San Antonio, Texas, April 1975.

[2j Tewarson, A., Tamanini, F., "Research and Levelopment for a Laboratory-Scale Flammability Test Method for Cellular Plastics, Final Report FMRC Serial No. 22524 , Grant No. RP-75-1-33A, Factory Mutual Engineerins, August 1976.

[3] Smith, E.E., ASTM STP 502, American Society for Testins Materials, Philadelphia, Pennsylvania (1972), pp. 119-134.

[4j Parker, W.J. and Lony, M.E., ibia, pp. 135-151.

[bj Hamilton, D.C. and Morgan, W.R., NACA Tech. Note 2836, 1952.

[6j Evans, D.D. and Breden, L.H., Fire Technology, Vol. 14, No. 2, pp. 85-96, May 1978.

[7] Babrauskas, V., "Performance of the OSU Rate of Heat Release Apparatus Using PMMA and Gaseous Fuels", Fire Safety Journal, 5, 9-20 (1983).

[8] Chamberlain, D.L., "Heat Release Rate Properties of Wood-Based Materials", NBSIR (to be published). 


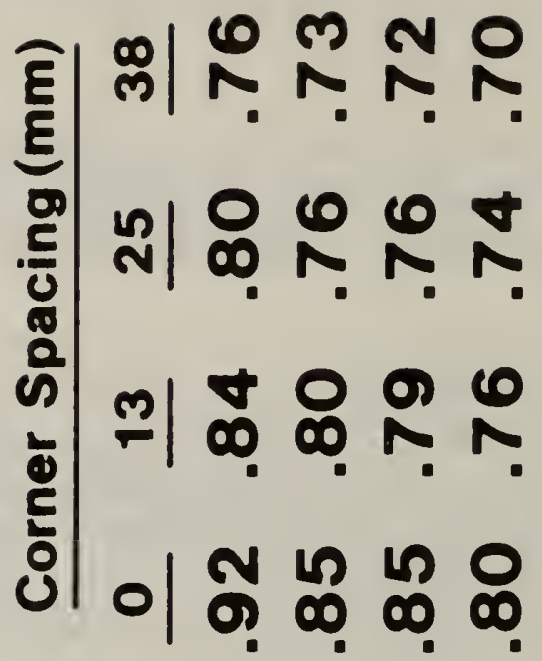

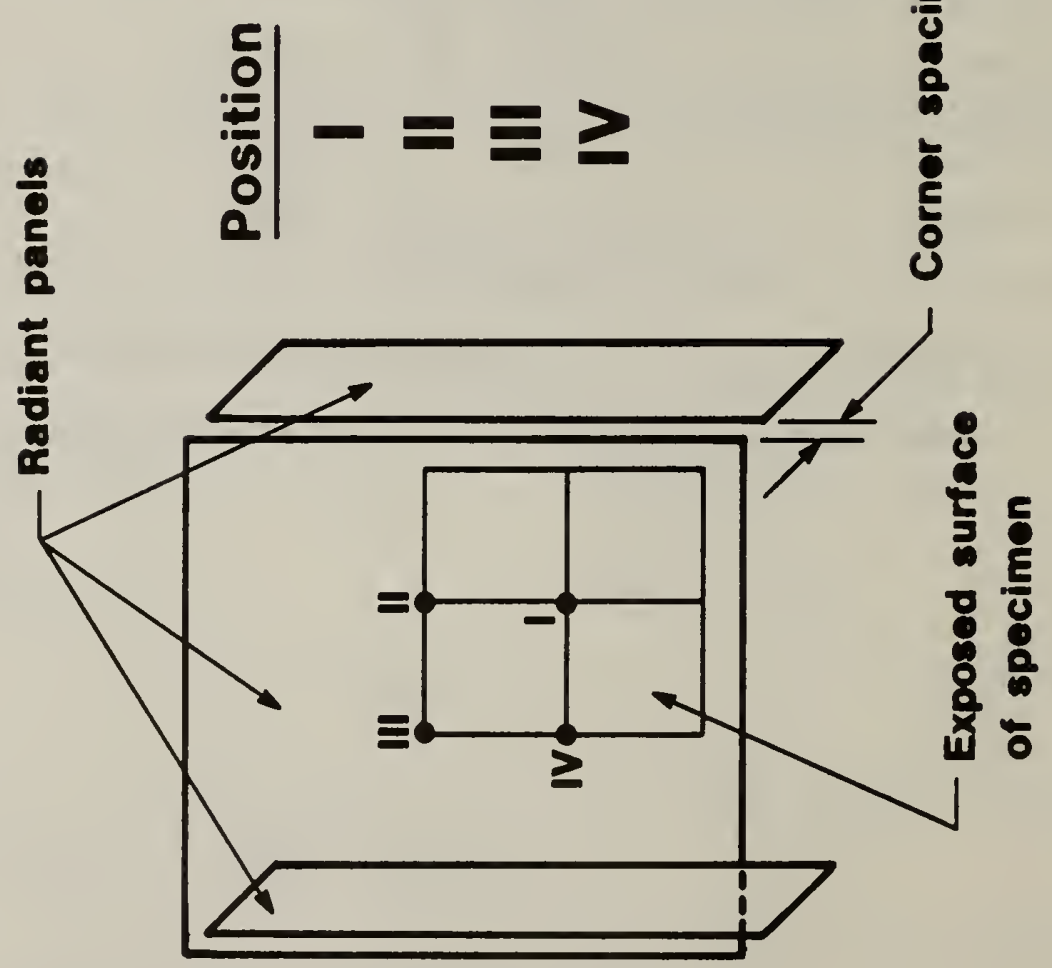

Dี 


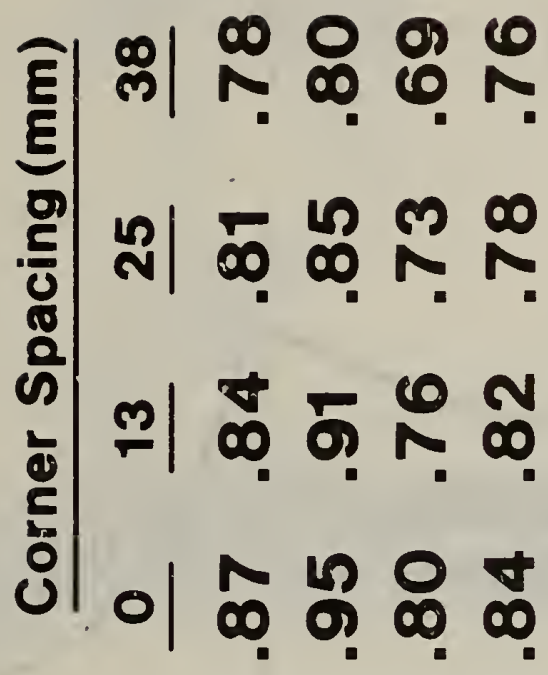
(1)

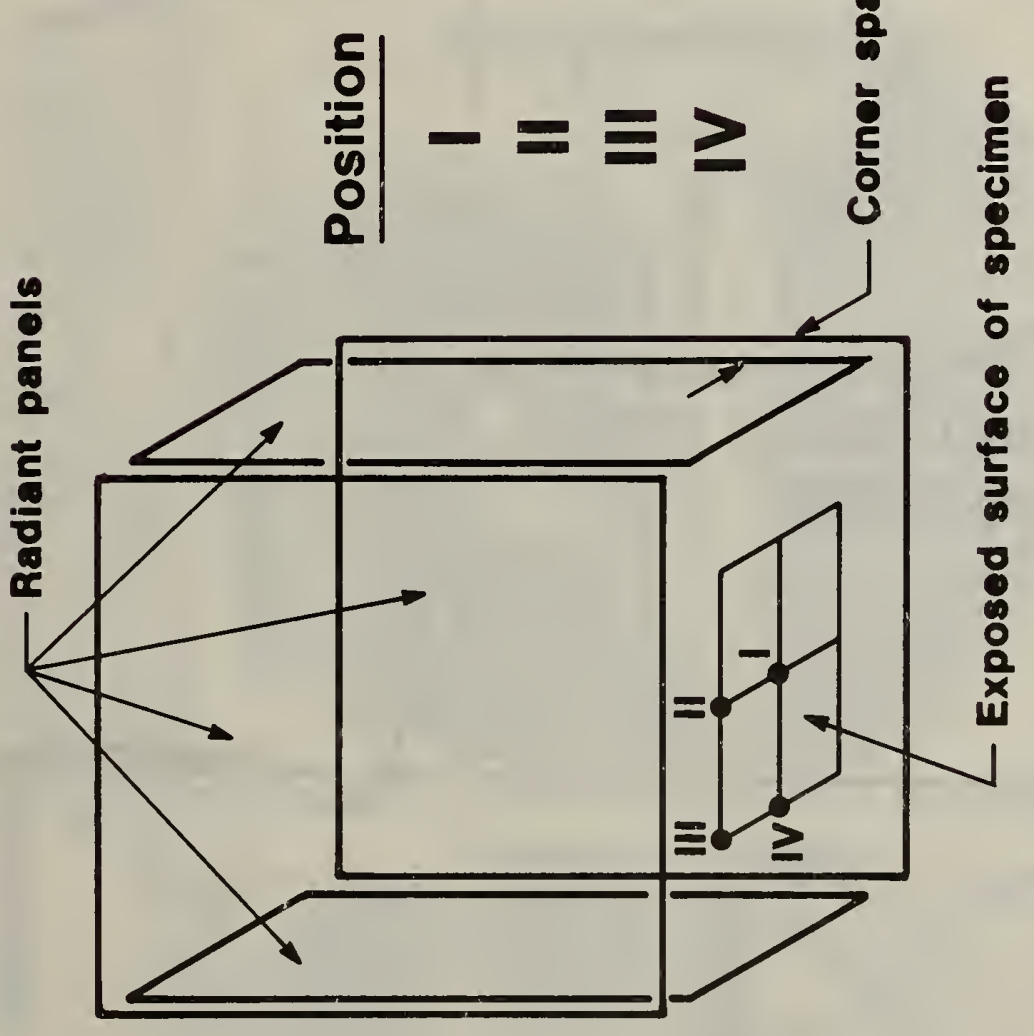


RESPONSE TIME

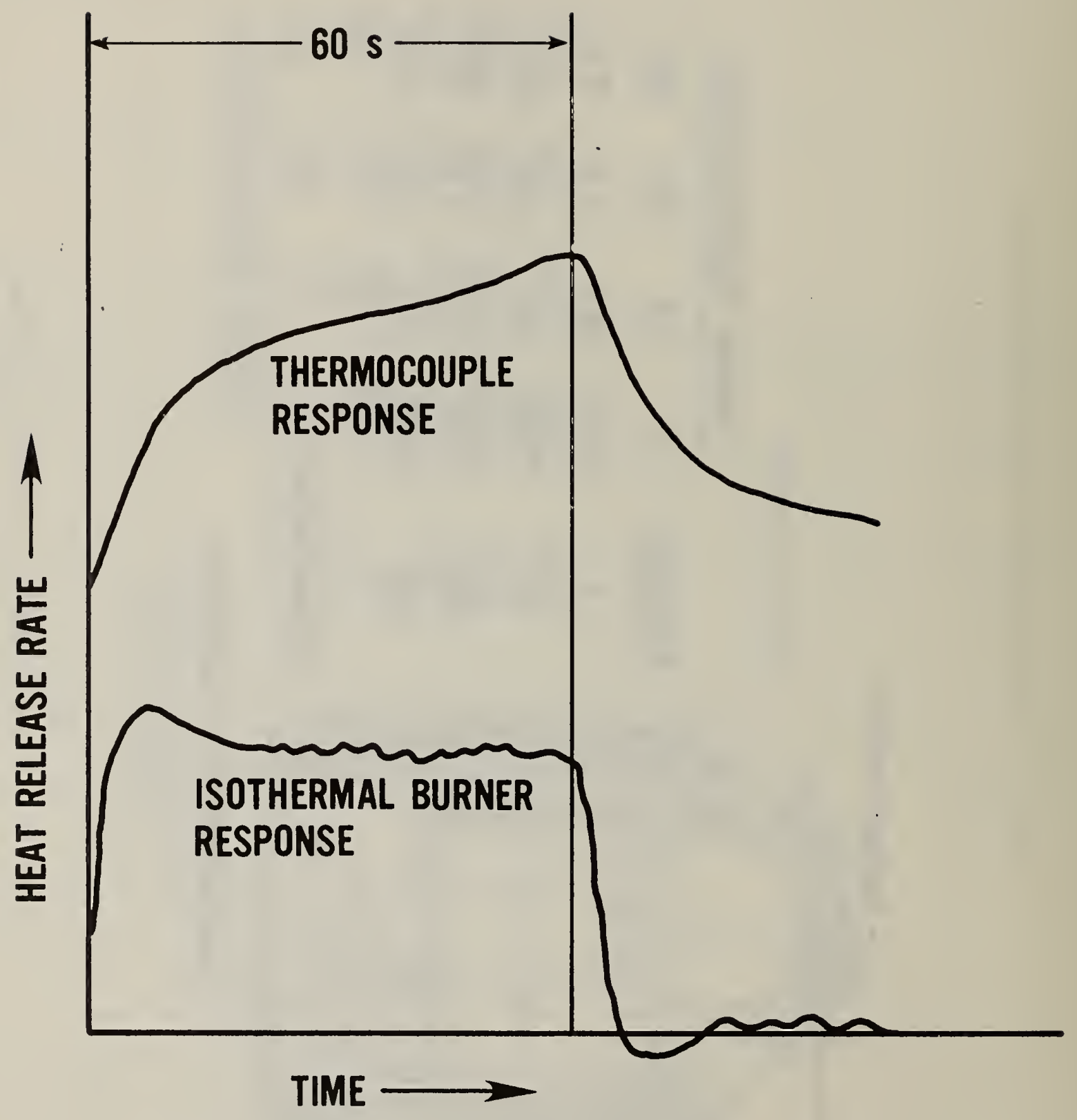

Figure 3. Response Time, NBS I Calorimeter 


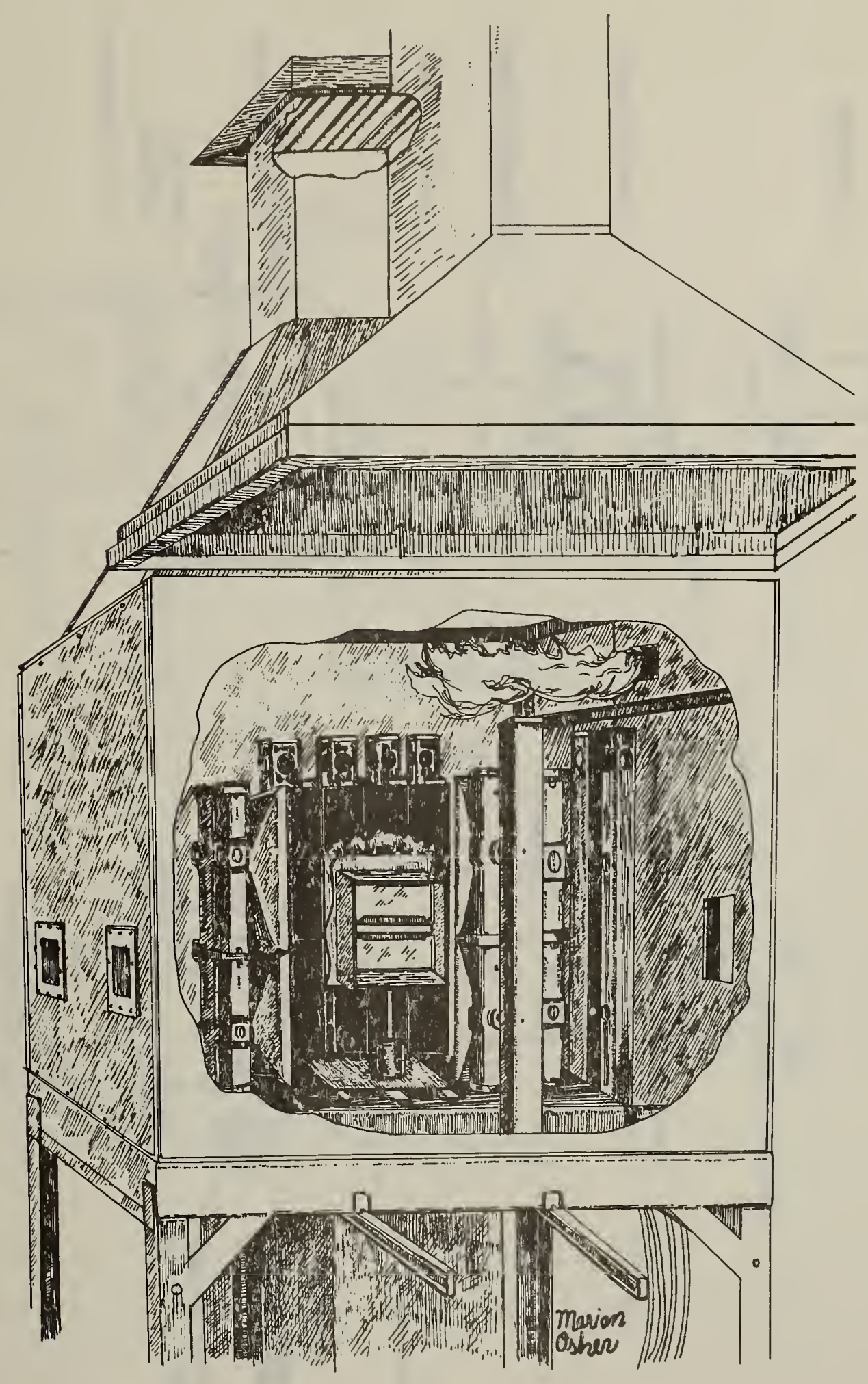

Figure 4. Artist's Rendition, NBS II Calorimeter 

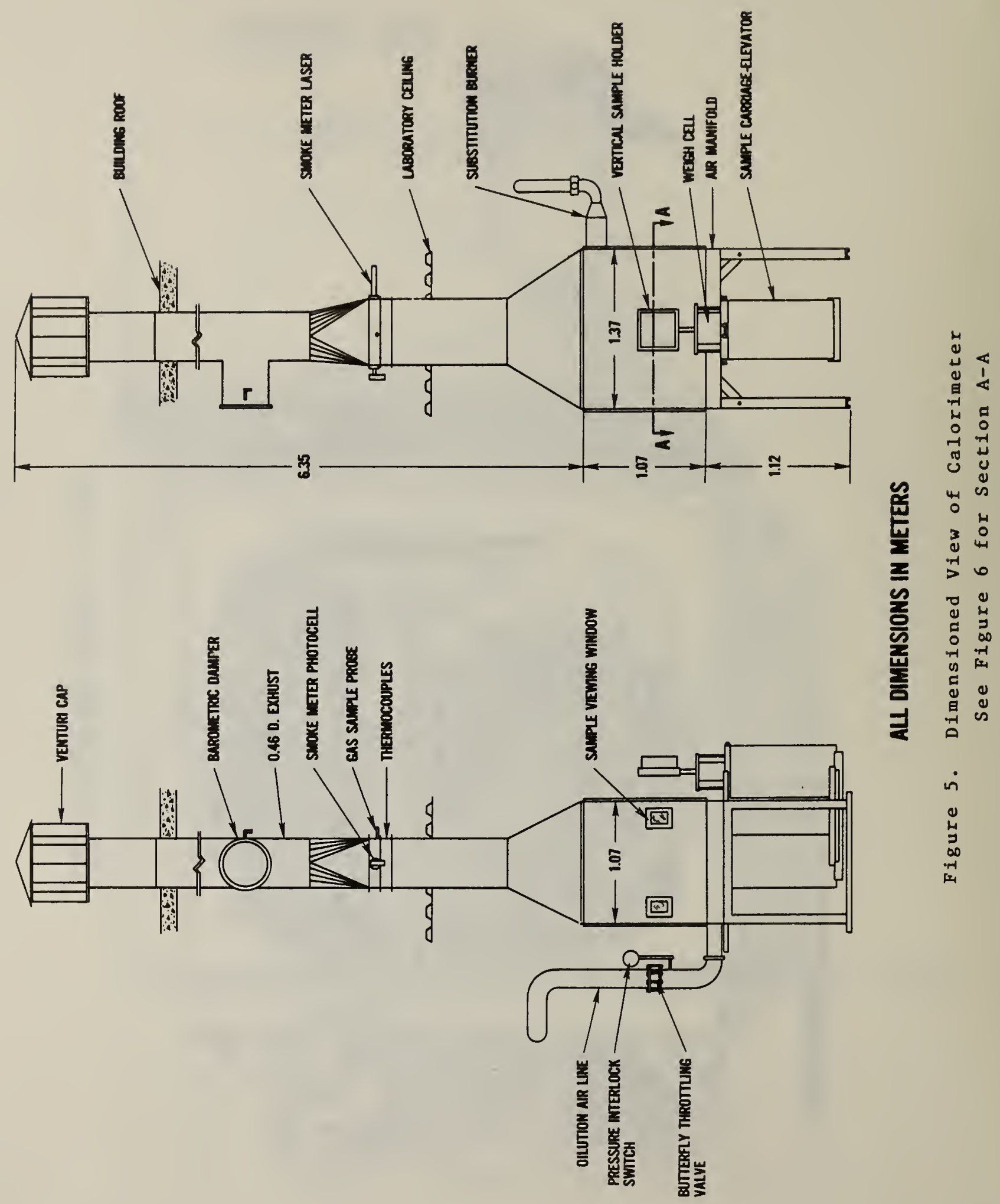


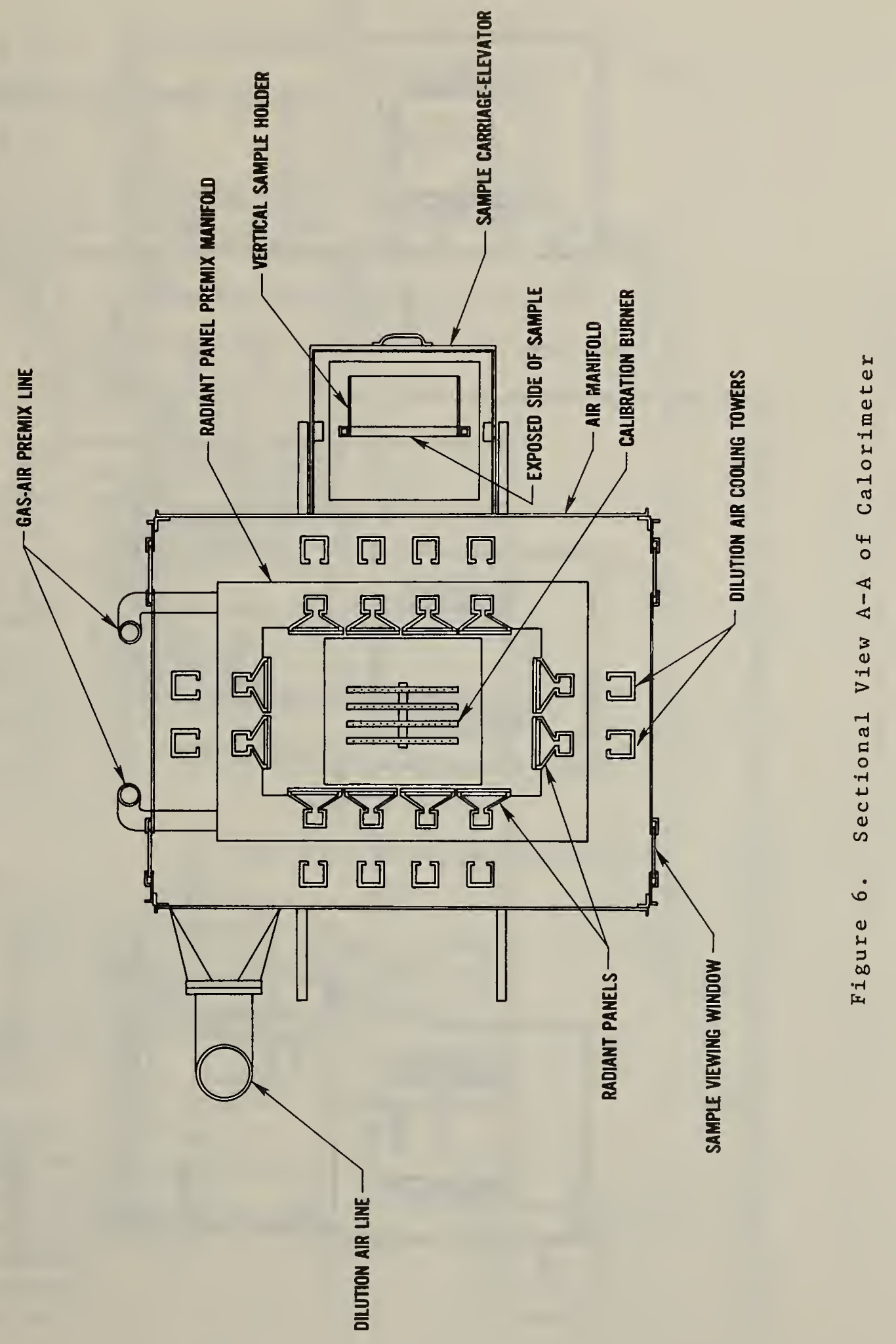




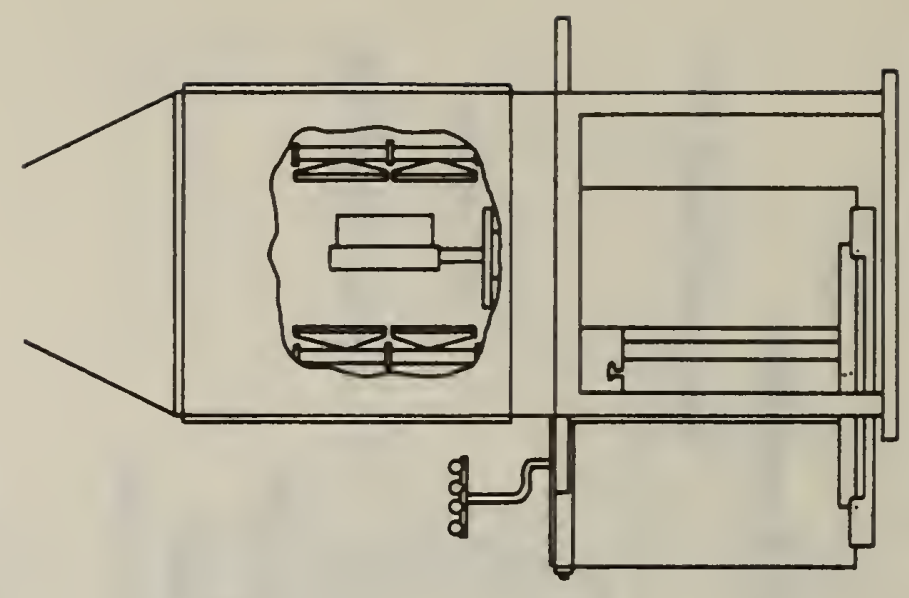

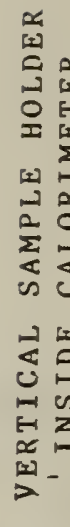

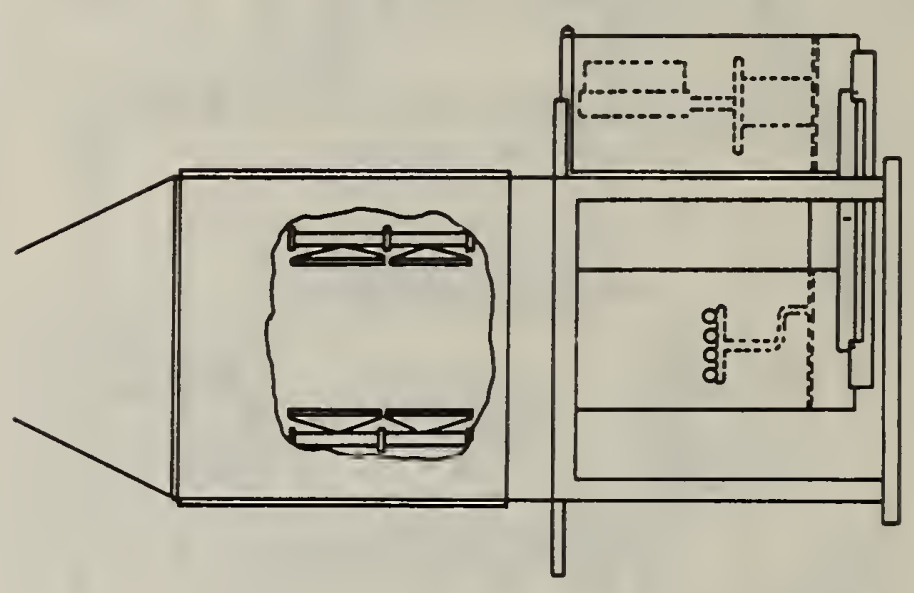

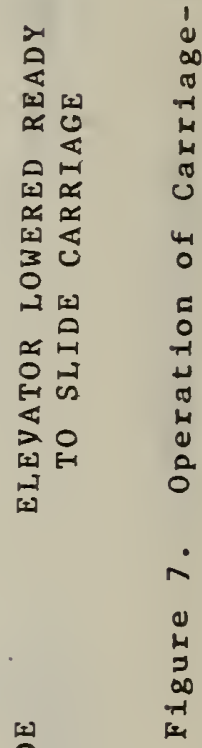

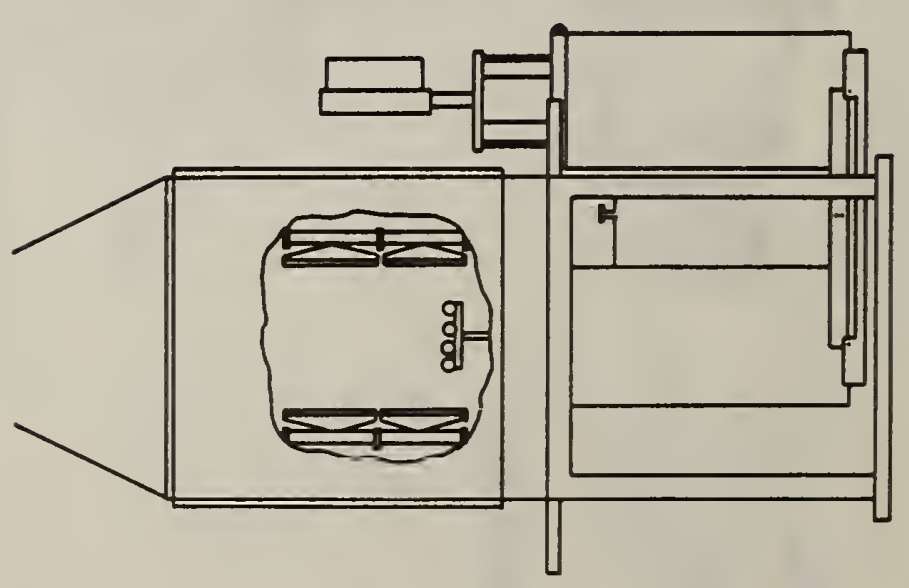

19 


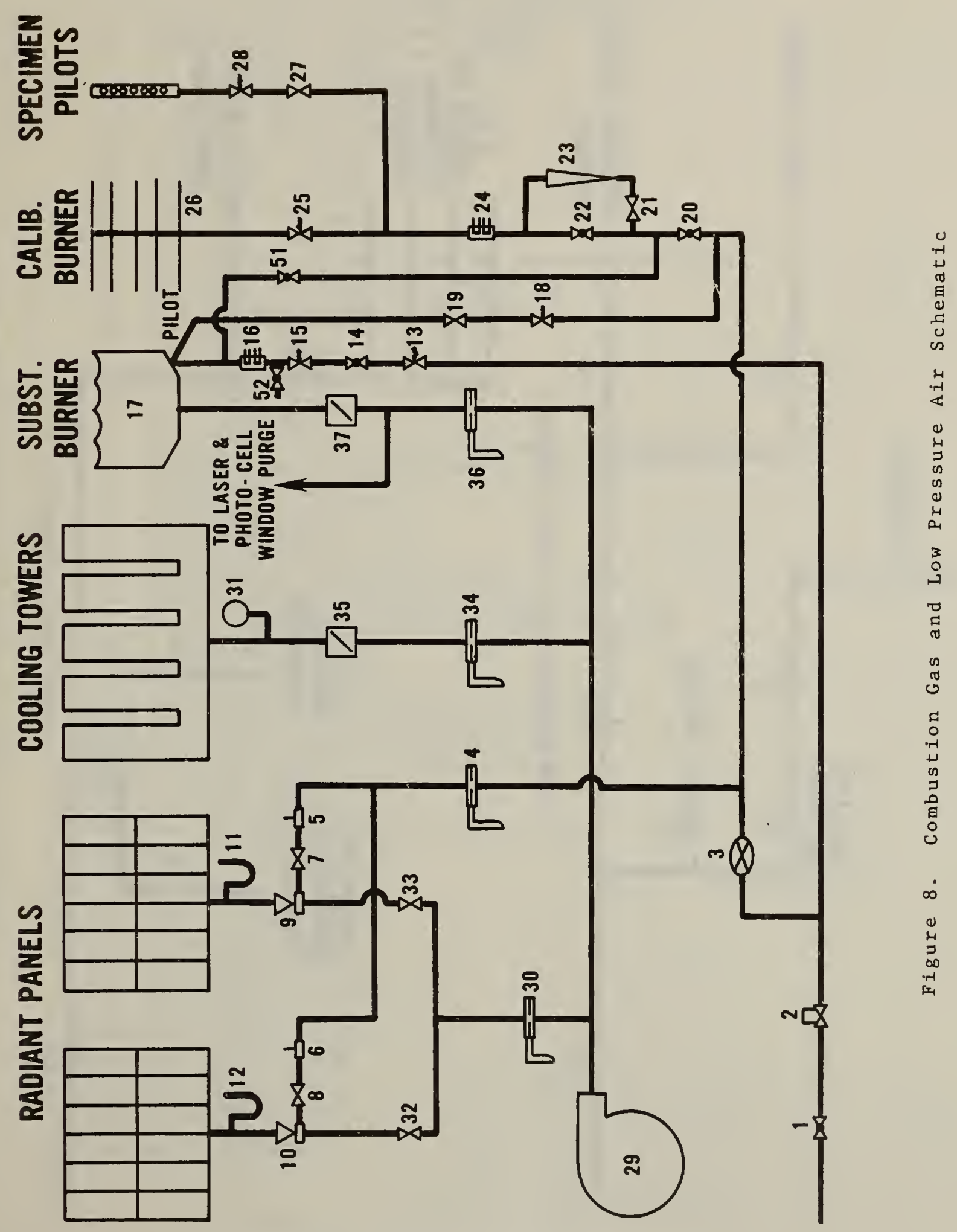




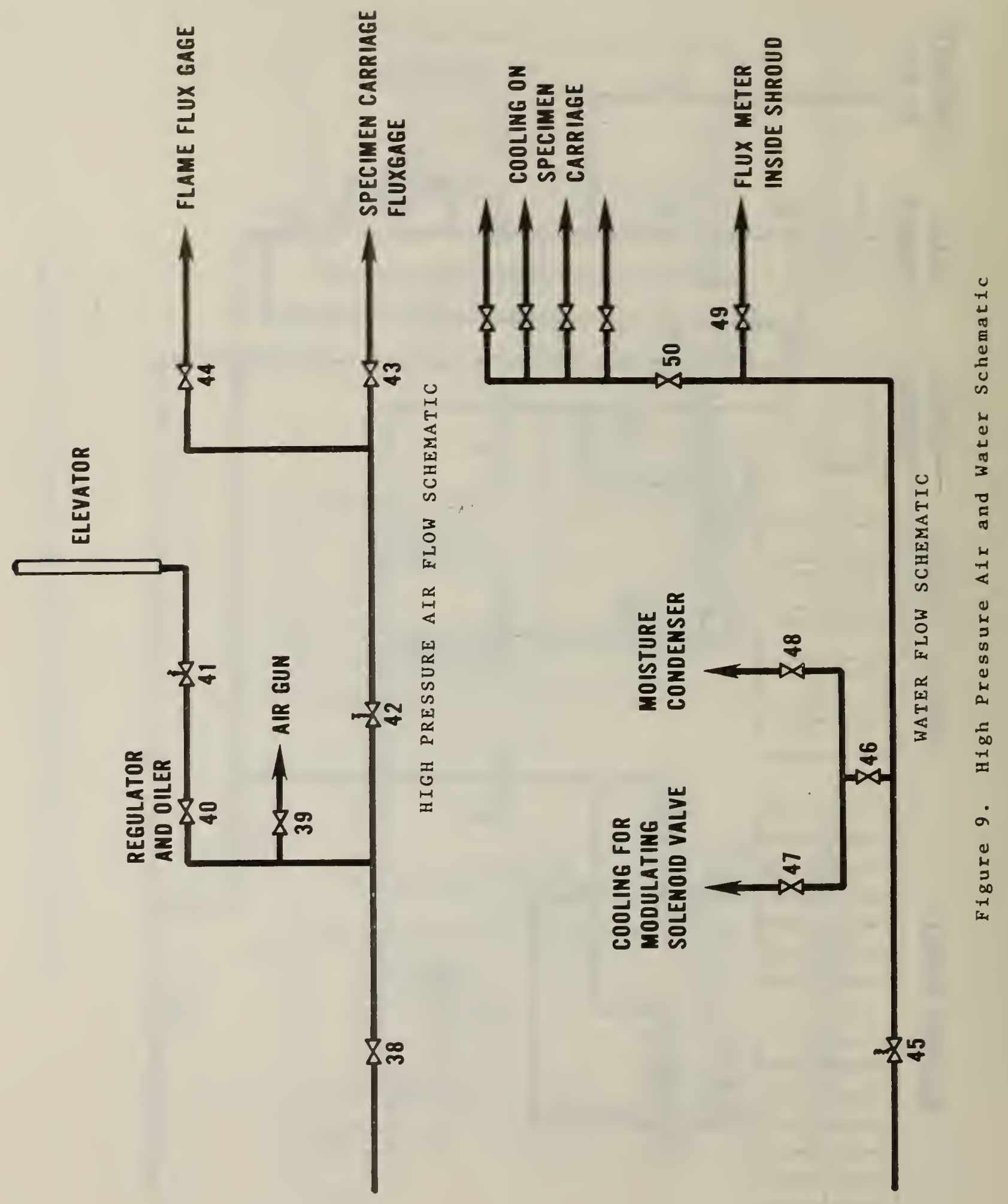




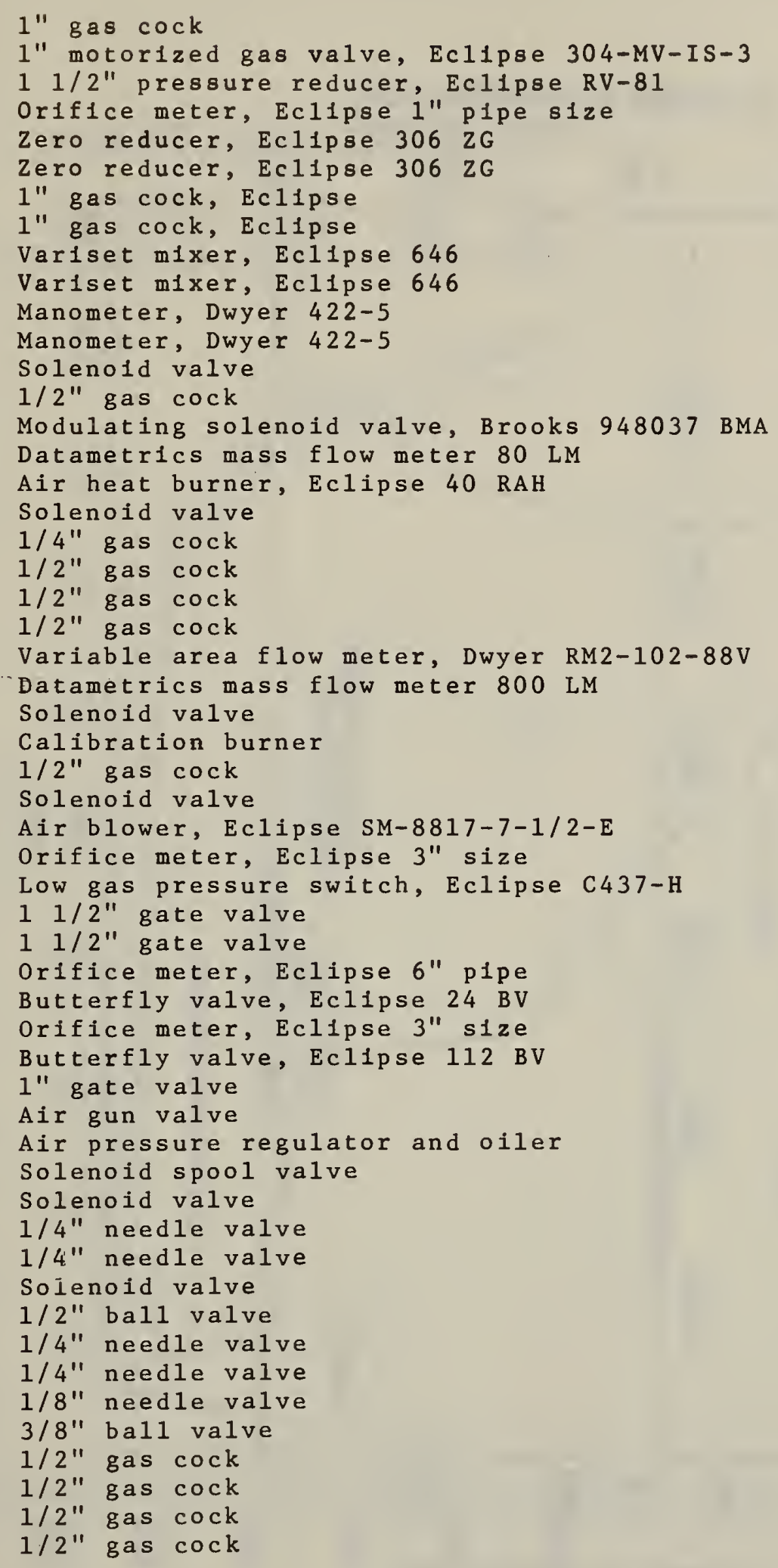

F1gure 10. Legend for F1gures 8 and 9 


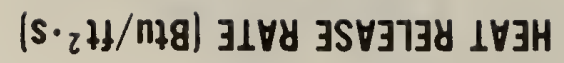

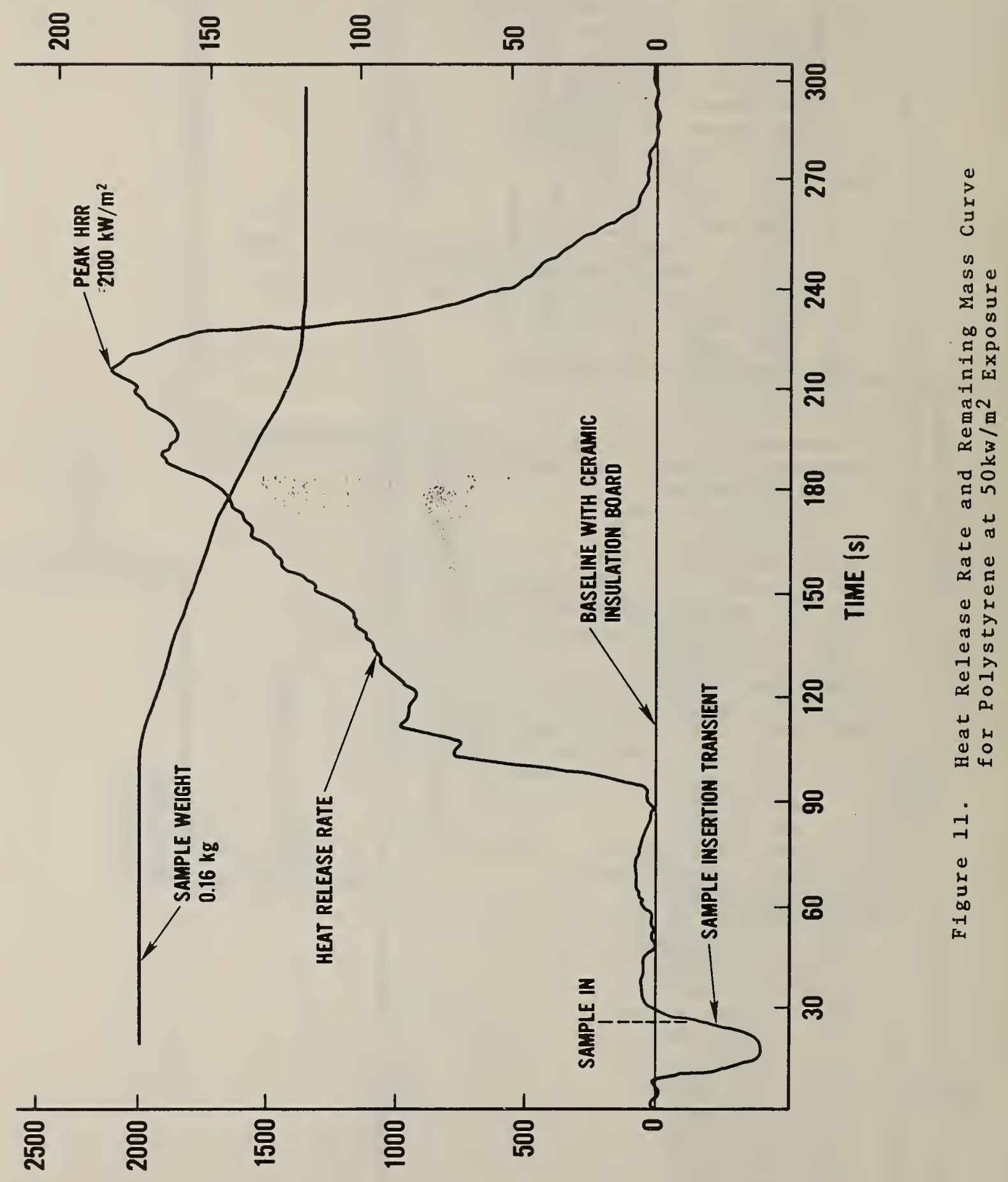

( $2 W / M Y) ~ 31 \forall Y ~ \exists S \forall 37 \exists y ~ 1 \forall \exists H$ 


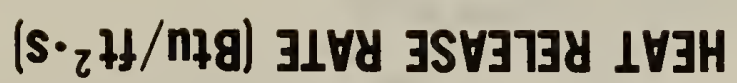

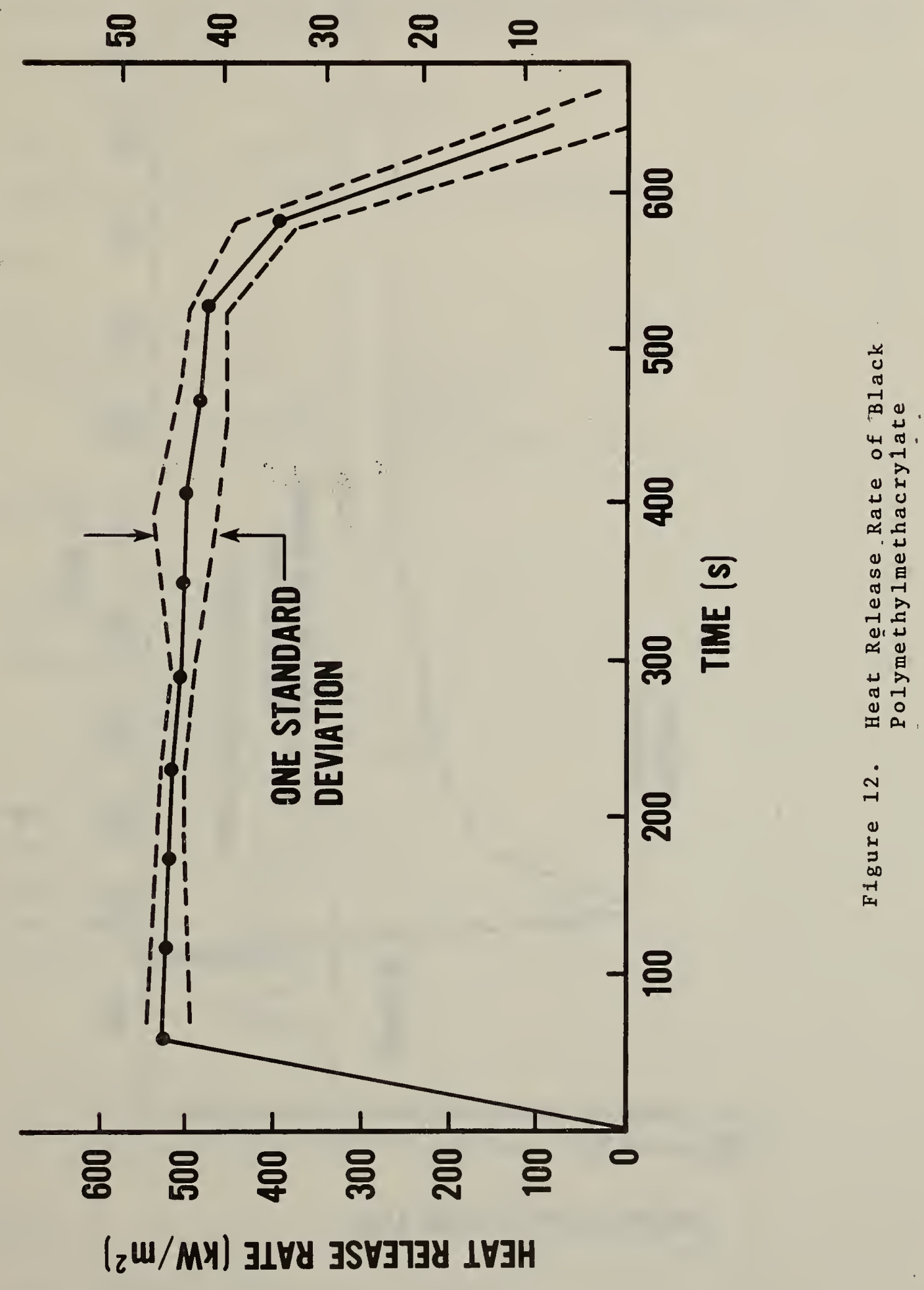




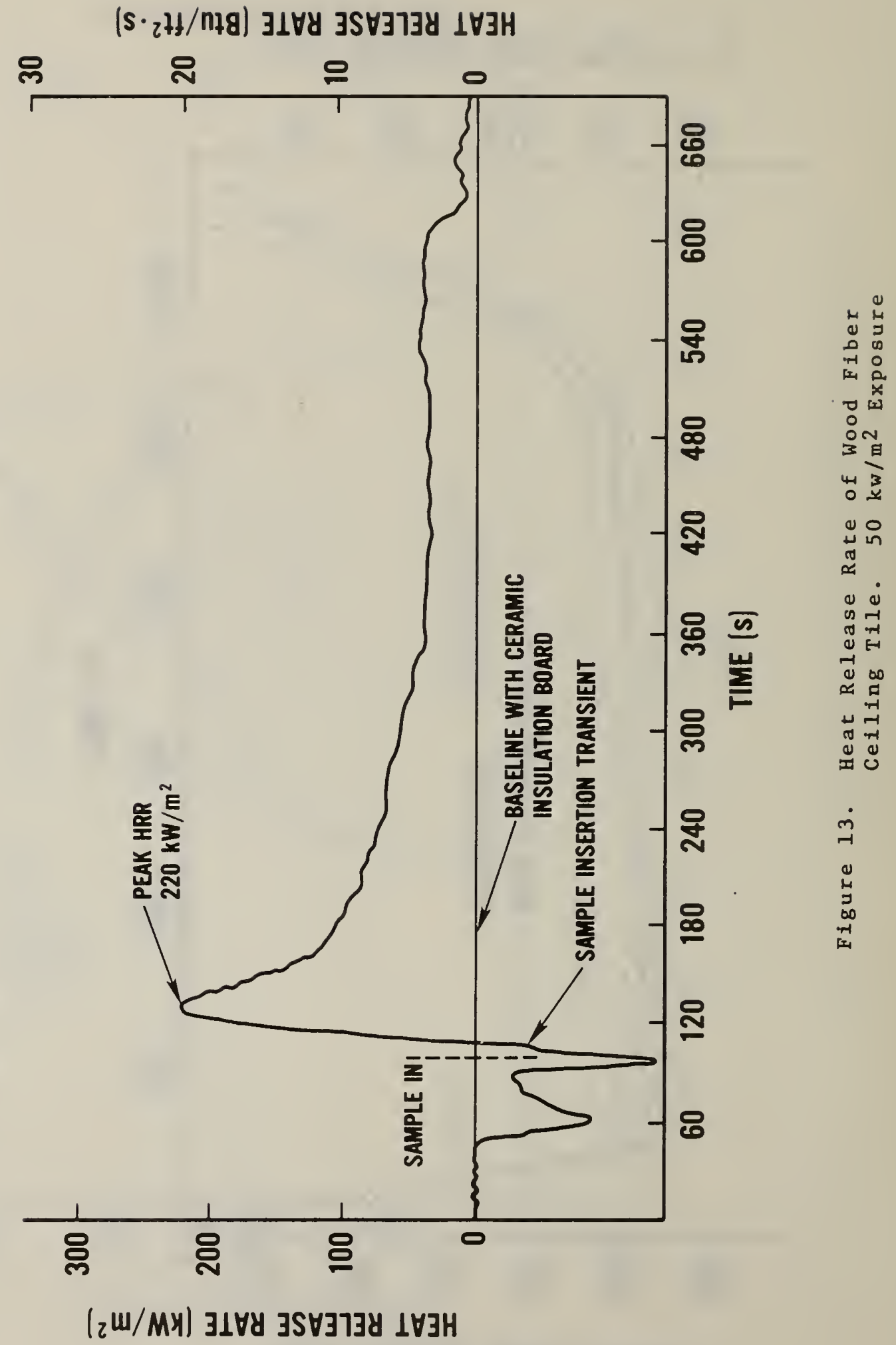


Table 1. Specification for New NBS Heat Release Rate Calorimeter

1. SPECIMEN :

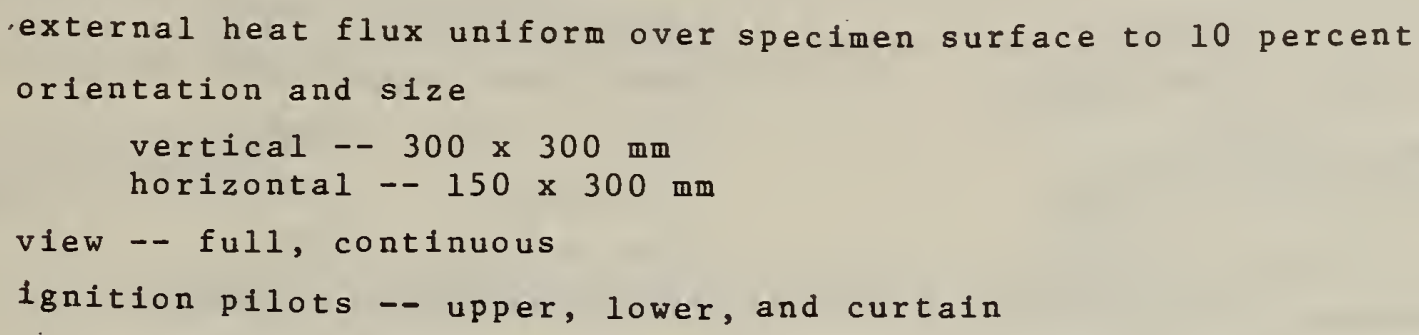

2. CAPACITY :

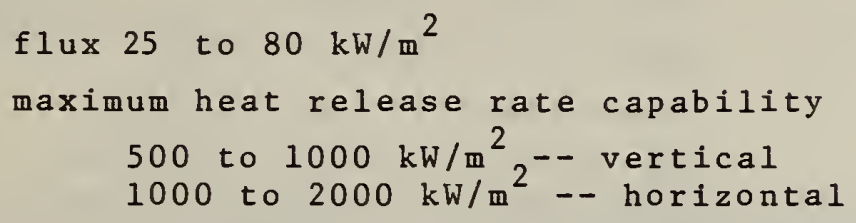

3. PERFORMANCE :

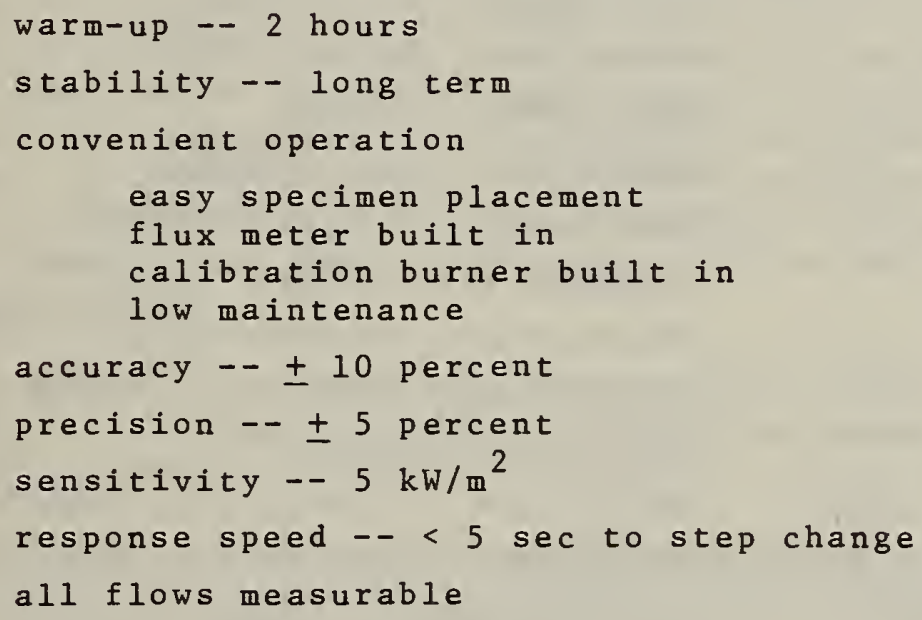

4. DATA:

(a) sample heat release and weight loss rates

(b) stack gas/smoke density and heat of combustion

5. RECORDING :

chart recorder and computer terminal 
Table 2. Engineering Drawing Schedule for Calorimeter*

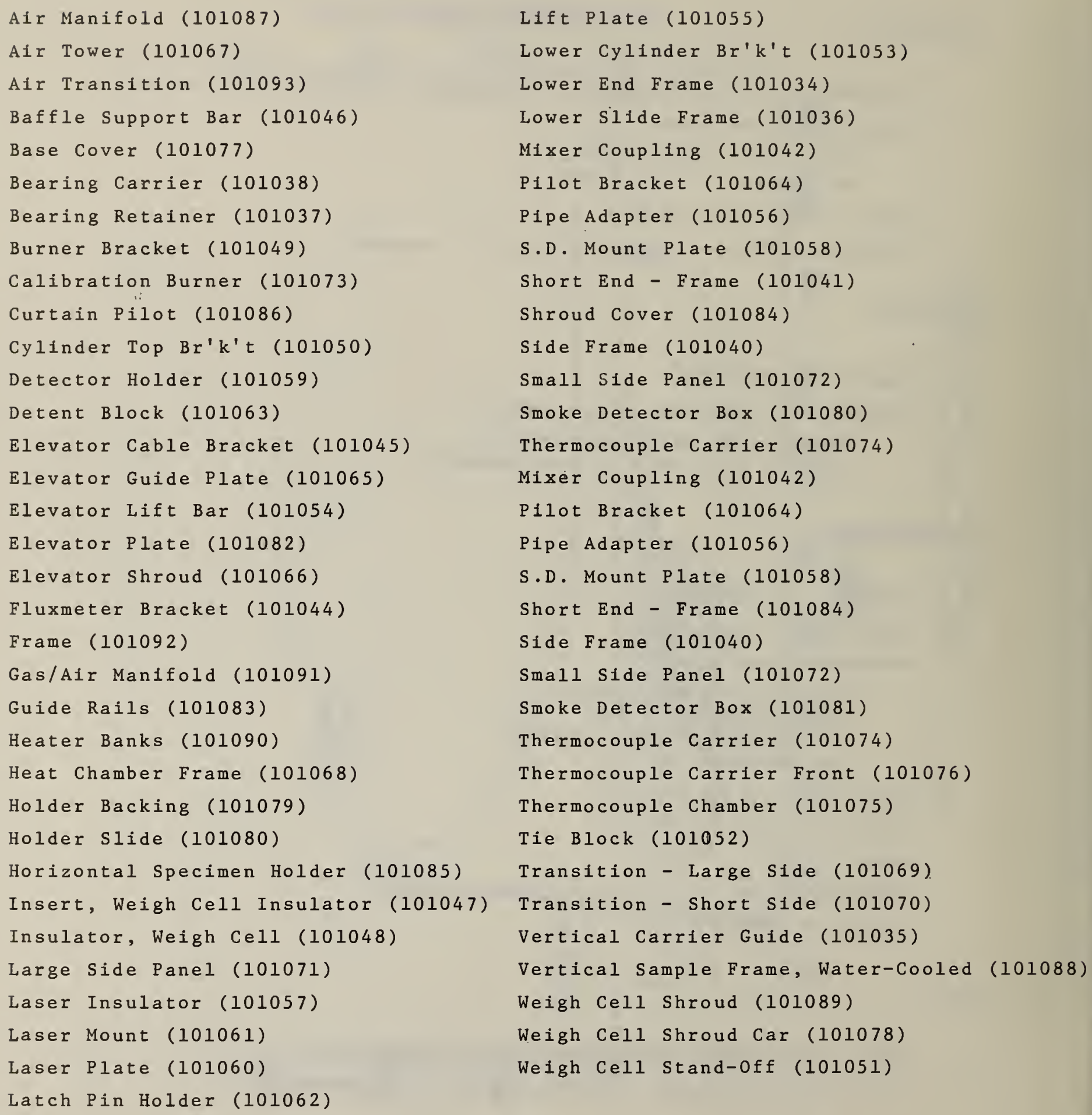

Lift Plate (101055)

Lower Cylinder Br'k't (101053)

Lower End Frame (101034)

Lower silde Frame (101036)

Mixer Coupling (101042)

Pilot Bracket (101064)

Pipe Adapter (101056)

S.D. Mount Plate (101058)

Short End - Frame (101041)

Shroud Cover (101084)

Side Frame (101040)

Small Side Panel (101072)

Smoke Detector Box (101080)

Thermocouple Carrier (101074)

Mixer Coupling (101042)

Pilot Bracket (101064)

Pipe Adapter (101056)

S.D. Mount Plate (101058)

Short End - Frame (101084)

Side Frame (101040)

Small Side Panel (101072)

Smoke Detector Box (101081)

Thermocouple Carrier (101074)

Thermocouple Carrier Front (101076)

Thermocouple Chamber (101075)

Tie Block (101052)

Transition - Large Side (101069).

Transition - Short Side (101070)

Vertical Carrier Guide (101035)

Vertical Sample Frame, Water-Cooled (101088)

Weigh Cell Shroud (101089)

Weigh Cell Shroud Car (101078)

Weigh Cell Stand-off (101051)

* Copies of the engineering drawings for the calorimeter may be obtained from the Engineering Design office of the National Bureau of Standards. 
NBS. I 14A (REV. 2-80)

U.S. DEPT. OF COMM.

BIBLIOGRAPHIC DATA

1. PUBLICATION OR REPORT NO.

SHEET (See instructions) NBSIR $83-2708$

2. Performing Organ. Report Nof 3. Publication Date

June 1983

4. TITLE AND SUBTITLE

Development of a Calorimeter for Simultaneous1y Measuring Heat Release and Mass Loss Rates

5. AUTHOR(S)

John Tordella and William H. Twilley

6. PERFORMING ORGANIZATION (If joint or other than NBS. see instructions)

7. Contract Grant No.

NATIONAL BUREAU OF STANDARDS

DEPARTMENT OF COMMERCE

8. Type of Report \& Period Covered

WASHINGTON, D.C. 20234

9. SPONSORING ORGANIZATION NAME AND COMPLETE ADDRESS (Street, CItY, 5tote, ZIP)

10. SUPPLEMENTARY NOTES

Document describes a computer program; SF-185, FIPS Software Summary, is attached.

11. ABSTRACT (A 200-word or less factual summary of most significant information. If document includes a significant bibliogrophy or literoture survey, mention it here)

A heat release rate calorimeter (designated as NBS II) was designed, built, and put into operation. Specimens may be burned vertically or horizontally without the use of reflectors to provide a uniform external radiant flux field. The flux range is 25 to $80 \mathrm{~kW} / \mathrm{m}^{2}$. Heat release rate, mass 1 loss rate, smoke, and heat of combustion of the unburned gaseous decomposition products are measured. The heat release rate measurement involves the use of a substitution burner technique which provides fast response. The ratio of the heat release to mass loss rates, the apparent heat of combustion, is provided as a function of time. The calorimeter may also be operated in other modes, e.g., stack temperature increase and oxygen depletion, to obtain the heat release rate.

Representative data are reported for wood and a number of synthetic polymers burned horizontally at a flux of $50 \mathrm{~kW} / \mathrm{m}^{2}$. These specimens generate considerable heat and a significant amount of uncombusted fuel.

A program involving thorough characterization of the instrument, obtaining reference heat release data for numerous materials, and conducting research in heat release rate and other flammability characteristics is recommended.

12. KEY WORDS (Six to twelve entries; alphabetical order; capitalize only proper names; and separate key words by semicolons) calorimeter; fire test; heat of combustion; heat release rate; mass loss rate.

13. AVAILABILITY

X Unlimited

For Official Distribution. Do Not Release to NTIS

$\square$ Order From Superintendent of Documents, U.S. Government Printing Office, Washington, D.C. 20402.

- Order From National Technical Information Service (NTIS), Springfield, VA. 22161
14. NO. OF

PRINTED PAGES

34

15. Price

$\$ 8.50$ 


